\title{
Study of acetylene poisoning of Pt cathode on proton exchange membrane fuel cell spatial performance using a segmented cell system
}

\author{
Tatyana V. Reshetenko*, Jean St-Pierre \\ Hawaii Natural Energy Institute, University of Hawaii, 1680 East-West Road, POST 109, Honolulu,
} HI 96822, USA

\begin{abstract}
Acetylene is a welding fuel and precursor for organic synthesis, which requires considering it to be a possible air pollutant. In this work, the spatial performance of a proton exchange membrane fuel cell exposed to $300 \mathrm{ppm} \mathrm{C}_{2} \mathrm{H}_{2}$ and different operating currents was studied with a segmented cell system. The injection of $\mathrm{C}_{2} \mathrm{H}_{2}$ resulted in a cell performance decrease and redistribution of segments' currents depending on the operating conditions. Performance loss was 20-50 mV at 0.1$0.2 \mathrm{~A} \mathrm{~cm}^{-2}$ and was accompanied by a rapid redistribution of localized currents. Acetylene exposure at $0.4-1.0 \mathrm{~A} \mathrm{~cm}^{-2}$ led to a sharp voltage decrease to $0.07-0.13 \mathrm{~V}$ and significant changes in current distribution during a transition period, when the cell reached a voltage of 0.55-0.6 V. A recovery of the cell voltage was observed after stopping the $\mathrm{C}_{2} \mathrm{H}_{2}$ injection. Spatial electrochemical impedance spectroscopy (EIS) data showed different segments' behavior at low and high currents. It was assumed that acetylene oxidation occurs at high cell voltage, while it reduces at low cell potential. A detailed analysis of the current density distribution, its correlation with EIS data and possible $\mathrm{C}_{2} \mathrm{H}_{2}$ oxidation/reduction mechanisms are presented and discussed.
\end{abstract}

Key words: PEMFC; Pt cathode; Acetylene; Airborne contaminant; Spatial EIS; Segmented cell

\section{Introduction}

* Corresponding author. Tel.: +1-808-593-1714; fax: +1-808-593-1719.

E-mail address: tatyanar@hawaii.edu (T.V. Reshetenko) 
The proton exchange membrane fuel cell (PEMFC) has been the subject of intensive research and development efforts for the last two decades due to its potentials. High efficiency, harmless emission products, low operating temperature and quiet operation have provided a wide range of fuel cell applications: from vehicle power sources instead of internal combustion engines to portable and stationary power generation systems. As fuel cell technology moves toward a mass-production stage, research has to address issues relating to the environments in which fuel cells are expected to operate. Currently available PEMFCs mostly use ambient air as the cathode oxidant, and ambient air contains a variety of impurities such as $\mathrm{SO}_{2}, \mathrm{H}_{2} \mathrm{~S}, \mathrm{NH}_{3}$ and $\mathrm{NO}_{\mathrm{x}}$. Major sources of air contaminants are vehicle and industrial exhausts in urban environments and some naturally occurring processes such as volcanic activities.

For the past fifteen years, the impacts of some air contaminants have been studied intensively. The first works were published in 2000-2001 [1, 2]. The effects of battlefield contaminants $\left(\mathrm{SO}_{2}, \mathrm{NO}_{2}\right.$, $\mathrm{CO}, \mathrm{C}_{3} \mathrm{H}_{8}$ and benzene) and some warfare agents (sarin, sulfur mustard, $\mathrm{CNCl}$, and $\mathrm{HCN}$ ) on airbreathing PEMFC were studied by J.M. Moore [1]. G. Mepsted presented a detailed study on the impacts of common urban atmospheric pollutants $\left(\mathrm{SO}_{2}, \mathrm{CO}\right.$, benzene, 1,3-butadiene and $\left.\mathrm{NH}_{3}\right)$ on membrane electrode assembly (MEA) performance and examined contaminant mitigation by filtration [2]. The following publications were focused mainly on the effects of common inorganic species on oxygen reduction reaction (ORR), membrane conductivity and MEA performance [312]. The effects of sulfur dioxide and related species were presented in papers [1, 2, 6-20], and the impacts of $\mathrm{NH}_{3}$ and $\mathrm{NO}_{\mathrm{x}}$ on fuel cell performance were reported in [1, 2, 6-12, 21-25]. Fuel cell performance under $\mathrm{NaCl}$ exposure was studied in [26, 27], impact of atmospheric aerosols was presented in [28]. At the same time, the selection of air contaminants ignores potentially hazardous 
organic compounds, and prior publications with organic species as oxidant pollutants are limited to warfare agents [1], benzene and 1,3-butadiene [1, 2], and some other hydrocarbons [29-31].

Air pollutants are particularly critical for fuel cell systems where air filters cannot be employed due to weight or volume limitations. Impurities affect fuel cell performance by different mechanisms. Some of them can adsorb on the catalyst surface, reduce electrochemically active area (ECA) and decrease ORR activity. Some contaminants may alter the ORR pathways by promoting or inhibiting particular elemental steps, for example changing a 4-electron ORR mechanism to 2-electron with the formation $\mathrm{H}_{2} \mathrm{O}_{2}$. Moreover, some pollutants may change the properties of MEA components, such as hydrophobicity or proton conductivity, which affect water management and may cause performance loss. Depending on the chemical nature of the contaminant and exposure time, its impact on the fuel cell may be reversible or permanent.

From an inventory of 260 air pollutants from the Environmental Protection Agency list, seven contaminants were chosen for detailed studies using a two tier selection process [32]. These seven pollutants are acetylene $\left(\mathrm{C}_{2} \mathrm{H}_{2}\right)$, propene $\left(\mathrm{C}_{3} \mathrm{H}_{6}\right)$, methyl methacrylate $\left(\mathrm{CH}_{2} \mathrm{C}\left(\mathrm{CH}_{3}\right) \mathrm{COOCH}_{3}\right)$, 2propanol $\left(\left(\mathrm{CH}_{3}\right)_{2} \mathrm{CHOH}\right)$, bromomethane $\left(\mathrm{CH}_{3} \mathrm{Br}\right)$, naphthalene $\left(\mathrm{C}_{10} \mathrm{H}_{8}\right)$ and acetonitrile $\left(\mathrm{CH}_{3} \mathrm{CN}\right)$, which are commonly used as solvents, welding and other fuels, cleaning agents, or for pest control. The selected contaminants belong to different classes of organic compounds and cover various functional groups, including alcohols, N-containing compounds, alkenes, alkynes, esters, aromatic rings and halides. As shown previously, all of them have serious negative impacts on Pt ECA and PEMFC performance [33-39]. 
As acetylene is widely used as welding fuel and a chemical reagent, it is considered to be a potential fuel cell contaminant. The chemical and electrochemical interaction and adsorption of $\mathrm{C}_{2} \mathrm{H}_{2}$ with $\mathrm{Pt}$ is a much investigated area due to wide studies of Pt-based catalysts for the oxidation and partial oxidation of various hydrocarbons [40] and studies of the anodic oxidation of organic fuels for the production of electrical energy [41-43]. The effects of $\mathrm{C}_{2} \mathrm{H}_{2}$ on ORR for a commercial Pt/C catalyst were investigated using the rotating ring disk electrode (RRDE) technique [37]. The results showed a complete loss of Pt ECA in the presence of acetylene, an increase in $\mathrm{H}_{2} \mathrm{O}_{2}$ production and a shift of the ORR onset potential in the negative direction by $330 \mathrm{mV}$. Studies on the impact of acetylene on single fuel cell performance revealed that high concentrations $(\sim 300 \mathrm{ppm})$ caused a drastic performance loss [34]. The evaluation of fuel cell performance with a single cell approach provides only an average of the local voltage, current and impedance values and does not reveal the spatial behavior of the cell. A segmented cell system is a powerful tool for understanding the details of locally resolved fuel cell processes such as local current distributions [44-49], gas and water management effects [50-54], stack and single cell diagnostic techniques [55-58], defect detection and localization methods [59-63], recirculation [64], and start-up and starvation impact [65-68]. However, there are only several publications in which segmented cells were applied to the study of anode poisoning with $\mathrm{CO}$ in a hydrogen stream [69-75]. At the same time, there are no any works on spatial PEMFC performance under cathode poisoning by airborne contaminants. Information about the current distribution is crucial and beneficial for understanding the poisoning process and mechanism, improving the PEMFC environmental adaptability and durability and developing mitigation strategies. This paper focuses on detailed studies of the spatial performance of a fuel cell exposed to $300 \mathrm{ppm} \mathrm{C}_{2} \mathrm{H}_{2}$ and operated at different current densities. In addition, spatial electrochemical impedance spectroscopy (EIS) was employed to understand and characterize the local PEMFC response under exposure to acetylene. 


\section{Experimental}

All the experiments were conducted on a single cell test station using Hawaii Natural Energy Institute's (HNEI) segmented cell system, which enables the simultaneous acquisition of spatially distributed data [57]. The segmented cell approach for this study builds upon the works of Ballard Power Systems Inc. [46], the German Aerospace Centre at Stuttgart [76] and Los Alamos National Laboratory (LANL) $[45,77]$. HNEI's segmented cell system is partially based on the LANL design using closed loop Hall sensors and an improved data acquisition system. These enhancements allow the system to perform simultaneous rather than sequential measurements of spatial EIS, spatial linear sweep voltammetry (LSV) and cyclic voltammetry (CV).

The segmented cell system consists of the cell hardware, the current transducer system, the data acquisition device and a single cell test station (Fig. 1). The current transducer system was custom designed. A closed loop Hall sensor (Honeywell CSNN 191) is employed for current sensing. For EIS measurements, these sensors show very little inductance over the entire frequency range of interest. The system allows the investigation of 10 current channels in a high (standard) current mode and 10 channels in a low current mode. The standard current mode enables the measurement of segment currents to $15 \mathrm{~A}$. The low current mode of the system yields maximum current measurements of $375 \mathrm{~mA}$ with an accuracy of $\pm 2.5 \%$, which is typical for CV or LSV experiments. Voltage and current signal data collection was performed with a National Instrument PXI data acquisition instrument operating on HNEI-developed LabView programs. This diagnostic tool enables the collection of spatially resolved information during a standard fuel cell experiment and it is operated as a single cell using a GRandalytics test station equipped with an Agilent N3300A DC electronic load and an UltraFlex series power supply from Lambda Electronic Inc. The test station 
has current and power limitations of $240 \mathrm{~A}$ and $1.2 \mathrm{~kW}$, respectively. Standardized single fuel cell testing protocols were used for recording locally resolved data. All experiments were carried out under galvanostatic control of the total cell current. Such operation minimized any impact from the segmented cell system and facilitated properties distribution measurememts without interference on the segments performance. The operation of the segmented cell system also represents operating conditions that are identical to applications because only the overall current is controlled while segments current and voltage are floating. The system was designed such that the segments voltages and cell voltage response were the same due to the relatively small fuel cell active area.

The segmented cell hardware is based on the HNEI $100 \mathrm{~cm}^{2}$ cell design. The hardware contains a segmented cathode flow field consisting of ten consecutive segments disposed along the path of a ten-channel serpentine flow field. Each segment has an area of $7.6 \mathrm{~cm}^{2}$ with its own distinct current collector. The same channel designs are used for both the segmented cathode and the standard anode flow fields (the reactant streams are arranged in a co-flow configuration).

The cell hardware was operated with standard $100 \mathrm{~cm}^{2}$ Gore MEAs. The anode and cathode electrodes were composed of a Pt/C catalyst with a loading of $0.4 \mathrm{mg}_{\mathrm{Pt}} \mathrm{cm}^{-2}$. The gasket material was made of Teflon, with thicknesses of $125 \mu \mathrm{m}$ for the anode and cathode. Sigracet $25 \mathrm{BC}$ was used as the anode and cathode GDLs. The cathode used a segmented GDL and gasket configuration, whereas a single GDL was applied at the anode, and the total active area of the MEA was $76 \mathrm{~cm}^{2}$.

During $\mathrm{C}_{2} \mathrm{H}_{2}$ exposure, the dry contaminant gas was injected into the humidified air stream, and the humidification of the gas was held constant by increasing the temperature setting of the humidifier unit. The anode/cathode testing conditions for the contamination experiments were $\mathrm{H}_{2} /$ air, 
2/2 stoichiometry, $100 / 50 \%$ relative humidity and $48.3 / 48.3 \mathrm{kPa}_{\mathrm{g}}$ backpressure. The cell temperature was $80^{\circ} \mathrm{C}$. The MEA was operated under galvanostatic control of the whole cell current in the range of $0.1-1.0 \mathrm{~A} \mathrm{~cm}^{-2}$ (based on the $76 \mathrm{~cm}^{2}$ active MEA area). Fresh MEAs were used for each fixed current test. The contamination experiment consists of three phases: (1) pre-poisoning period with neat air, (2) poisoning until the cell voltage reached a steady value and (3) recovery, when the $\mathrm{C}_{2} \mathrm{H}_{2}$ injection was stopped to evaluate the cell's self-recovery with air.

The polarization curves (VI curves) in the $\mathrm{H}_{2}$ /air gas configuration were measured under the same conditions as the contamination experiment. VI curve measurements were also performed in the $\mathrm{H}_{2} / \mathrm{He}+\mathrm{O}_{2}$ (21 vol.\%) and $\mathrm{H}_{2} / \mathrm{O}_{2}$ gas configurations. To maintain a constant water transport in the cell for any given total cell current density, the flow rates of $\mathrm{He}+\mathrm{O}_{2}$ and $\mathrm{O}_{2}$ were identical to the rates used during the air operation with a stoichiometry of 2. Consequently, the stoichiometry of $\mathrm{He}+\mathrm{O}_{2}$ remained 2, whereas the stoichiometry of $\mathrm{O}_{2}$ increased to 9.5. The resulting three different VI curves $\left(\mathrm{H}_{2} /\right.$ air, $\mathrm{H}_{2} / \mathrm{He}+\mathrm{O}_{2}$ and $\left.\mathrm{H}_{2} / \mathrm{O}_{2}\right)$ were used to determine a segment's activation, ohmic and mass transfer (permeability and diffusion) overpotentials, as described previously [57].

The VI curve measurements and contamination experiments were combined with EIS to determine the cell's and segments' high-frequency resistances (HFR) and to measure the electrochemical impedance spectra for all ten segments and the overall cell. The selected frequency range for the EIS experiments was $0.05 \mathrm{~Hz}$ to $10 \mathrm{kHz}$, and the amplitude of the sinusoidal current signal perturbation was $2 \mathrm{~A}$, which resulted in a cell voltage response of $10 \mathrm{mV}$ or lower. The HFR was determined from the intercept of the EIS with the x-axis at higher frequencies. 
CV experiments were conducted to determine the ECA using a Parstat 2273 potentiostat/galvanostat from Princeton Applied Research and Solartron SI 1287/electrochemical interface. CVs were performed at a cell temperature of $35^{\circ} \mathrm{C}$ with a scan rate of $20 \mathrm{mV} \mathrm{s}^{-1}$, whereas $100 \%$ humidified hydrogen and nitrogen were supplied to the reference/counter and working electrodes, respectively, at a flow rate of $0.7501 \mathrm{~min}^{-1}$. For each measurement, three cycles were applied over a potential range from -0.015 to $1.1 \mathrm{~V}$ vs. the hydrogen reference electrode (HRE). The hydrogen desorption peak area of the third cycle was used to determine the ECA. Hydrogen crossover experiments were performed at the same temperature and flow conditions as the ECA experiments using a single potential sweep from 0.1 to $0.4 \mathrm{~V}$ vs. the $\mathrm{HRE}$ at a scan rate of $0.1 \mathrm{mV} \mathrm{s}^{-1}$.

Before $\mathrm{C}_{2} \mathrm{H}_{2}$ exposure, the segmented cell was assembled using established procedures, conditioned and subjected to a set of diagnostic tests. The beginning of test (BOT) diagnostics consisted of CV to determine the ECAs of the electrodes, LSV to determine the hydrogen crossover current of the cell and measurement of VI curves with spatial EIS using the $\mathrm{H}_{2} /$ air, $\mathrm{H}_{2} / \mathrm{He}+\mathrm{O}_{2}$ and $\mathrm{H}_{2} / \mathrm{O}_{2}$ gas configurations to determine the performance, overpotential distributions and impedance responses of the cell. The same diagnostic tests (end of test (EOT)) were repeated after the $\mathrm{C}_{2} \mathrm{H}_{2}$ experiment. A comparison of the results before and after the contaminant exposure provided insight into the effects of acetylene on the spatial properties of the cell.

\section{Results and discussions}

\subsection{Fuel cell operation at low current density}

Figs. 2 and 3 present profiles of the segment voltages and current densities normalized to its initial values vs. experiment time at 0.1 and $0.2 \mathrm{~A} \mathrm{~cm}^{-2}$, respectively. The prepoisoning period was performed with $\mathrm{H}_{2} /$ air for $16-17$ hours. The segments voltages and the overall cell voltage were 
$0.817 \mathrm{~V}$ at $0.1 \mathrm{~A} \mathrm{~cm}^{-2}$ and $0.770 \mathrm{~V}$ at $0.2 \mathrm{~A} \mathrm{~cm}^{-2}$. The initial current density distribution was in the range of $0.08-0.13 \mathrm{~A} \mathrm{~cm}^{-2}$ in the case of an overall current density of $0.1 \mathrm{~A} \mathrm{~cm}^{-2}$. An increase in total current density to $0.2 \mathrm{~A} \mathrm{~cm}^{-2}$ led to the current distribution in the range from 0.17 to $0.23 \mathrm{~A} \mathrm{~cm}^{-2}$. The performances of individual segments were constant and did not change significantly with time during the prepoisoning stage. After the injection of $300 \mathrm{ppm} \mathrm{of} \mathrm{C}_{2} \mathrm{H}_{2}$ into the air stream, a decrease in segments voltages together with current density redistribution were observed. At steady state, the voltage loss was 30 and $50 \mathrm{mV}$ at 0.1 and $0.2 \mathrm{~A} \mathrm{~cm}^{-2}$, respectively, and the current density redistribution exhibited similar behavior: the inlet segments were characterized by lower performance than the outlet.

Under $\mathrm{C}_{2} \mathrm{H}_{2}$ exposure at $0.1 \mathrm{~A} \mathrm{~cm}^{-2}$, inlet segments 1-4 showed the lowest current density values and the outlet segments exhibited an increase in produced current. A decrease in the inlet segments' performance reaching a value as high as $62 \%$ of their initial performance occurred due to the adsorption of $\mathrm{C}_{2} \mathrm{H}_{2}$ on the Pt cathode, and its further conversion was most likely at the inlet part of the cell, which led to a decrease in $\mathrm{C}_{2} \mathrm{H}_{2}$ concentration downstream and kept the cathode outlet unpoisoned. Moreover, operation of the cell in the galvanostatic mode required obtaining a constant current out of the entire cell, and because the current of the inlet segments decreased, an increase of $42 \%$ in the current of segments 7-10 occurred. Similar current density behavior was found under CO poisoning [69-75]. Current density redistribution varied in the range of $+65 \%$ for segments $9-10$ and $-95 \%$ for segments $1-2$ at $0.2 \mathrm{~A} \mathrm{~cm}^{-2}$. The cell and segments partially recovered their performances after stopping $\mathrm{C}_{2} \mathrm{H}_{2}$ injection into the air stream. The voltage of the cell operating at $0.1 \mathrm{~A} \mathrm{~cm}^{-2}$ reached $0.790 \mathrm{~V}$ vs. an initial value of $0.817 \mathrm{~V}$, whereas the voltage after recovery was 0.747 vs. $0.770 \mathrm{~V}$ at $0.2 \mathrm{~A} \mathrm{~cm}^{-2}$. Moreover, for the last case, the segment current densities did not 
recover completely after $23 \mathrm{~h}$ of operation with pure air. Table 1 summarizes the details of performance under acetylene exposure at different current densities.

Spatial EIS data for all ten segments and the overall cell, recorded at 0.1 and $0.2 \mathrm{~A} \mathrm{~cm}^{-2}$, are presented in Figs. 4 and 5, respectively. The initial EIS spectra were recorded during the prepoisoning stage after operation with pure air for 14-15 h. The EIS curves of the fuel cell operated without any air impurities consist of several arcs: a high-frequency anode arc attributed to the hydrogen oxidation reaction (HOR), which is usually negligible but can sometimes be distinguished at low current operation; a high-frequency cathode loop due to a charge transfer resistance and double layer capacitance of ORR; and a low-frequency arc presenting mass transfer limitations at the cathode [78]. There is an increase in diameter of the low-frequency mass transfer loop from the inlet to the outlet segments due to $\mathrm{O}_{2}$ depletion and water accumulation $[52,53,75]$.

After $1 \mathrm{~h}$ of $\mathrm{C}_{2} \mathrm{H}_{2}$ injection at $0.1 \mathrm{~A} \mathrm{~cm}^{-2}$, there is an increase in the cathode charge transfer resistance of segments 1-3 (Fig. 4). However, in the case of $0.2 \mathrm{~A} \mathrm{~cm}^{-2}$, the impact of $\mathrm{C}_{2} \mathrm{H}_{2}$ on the EIS response after $1 \mathrm{~h}$ of exposure is not very significant (Fig. 5). Further $\mathrm{C}_{2} \mathrm{H}_{2}$ injection within 5$50 \mathrm{~h}$ leads to a continuous increase in impedance for segments $1-3$ at $0.1 \mathrm{~A} \mathrm{~cm}^{-2}$ and segments $1-4$ at $0.2 \mathrm{~A} \mathrm{~cm}^{-2}$, whereas the other segments demonstrate a slight decrease in impedance due to their increased performances. Thus, acetylene affects mostly the inlet part of MEA during operation at low current, and its impact is severe in the case of $0.2 \mathrm{~A} \mathrm{~cm}^{-2}$, when cell voltage reaches $\sim 0.72 \mathrm{~V}$.

$\mathrm{C}_{2} \mathrm{H}_{2}$ exposure was stopped after $50 \mathrm{~h}$ of poisoning. Operation with pure air within $1 \mathrm{~h}$ results in a decrease in charge transfer resistance for inlet segments 1-3 and a slight increase of impedance responses for the other segments at $0.1 \mathrm{~A} \mathrm{~cm}^{-2}$. Recovery for $1 \mathrm{~h}$ at $0.2 \mathrm{~A} \mathrm{~cm}^{-2}$ leads to the same 
spatial behavior: a decrease in impedance for segments 1-4 and a slight increase in impedance for segments 5-10. However, a low-frequency inductive loop was observed for segments 1 and 2. Lowfrequency inductive behavior in PEMFC was previously observed during operation with $\mathrm{H}_{2}$ containing CO [75, 79-90]. R.D. Armstrong and M. Henderson described a general mechanism consisting of two successive electron transfer steps involving the formation of an adsorbed intermediate species and explaining the appearance of low-frequency inductance under certain conditions [91]. Further studies were performed by D.A. Harrington and B.E. Conway [92], ChuNan Cao [93], J.-P. Diard et al [94] and P. Córdoba-Torres et al [95]. The observation of lowfrequency inductance during recovery at $\sim 0.7-0.75 \mathrm{~V}$ allows us to assume that there are successive reactions involving $\mathrm{C}_{2} \mathrm{H}_{2}$ and its adsorbed species with formation of an intermediate on the $\mathrm{Pt}$ electrode. Cathode recovery within $17 \mathrm{~h}$ at $0.1 \mathrm{~A} \mathrm{~cm}^{-2}$ results in a slight increase in the impedance of segments 1-4 and a slight decrease for other segments. In the case of operation at $0.2 \mathrm{~A} \mathrm{~cm}^{-2}$, a further decrease in cathode charge transfer resistance was revealed for segments 1 and 2, and others demonstrated slight variations, but the inlet segments did not reach their initial state.

\subsection{Fuel cell operation at high current density}

Profiles of the segments' voltages and normalized current densities recorded at total cell current densities of 0.4 and $1.0 \mathrm{~A} \mathrm{~cm}^{-2}$ are shown in Figs. 6 and 7. The voltage and current profiles for the cell operated at $0.6 \mathrm{~A} \mathrm{~cm}^{-2}$ are similar to the results at $1.0 \mathrm{~A} \mathrm{~cm}^{-2}$, and the details of the test are presented in Table 1. During the prepoisoning phase, the cell and segments' voltages were 0.750 and $0.662 \mathrm{~V}$ at 0.4 and $1.0 \mathrm{~A} \mathrm{~cm}^{-2}$, respectively. The range of measured individual segment current densities was $0.37-0.48 \mathrm{~A} \mathrm{~cm}^{-2}$ for the cell operated at an overall current density of $0.4 \mathrm{~A} \mathrm{~cm}^{-2}$, whereas the initial current density distribution was from 0.88 to $1.15 \mathrm{~A} \mathrm{~cm}^{-2}$ for the cell operated at an overall current density of $1.0 \mathrm{~A} \mathrm{~cm}^{-2}$. 
The results of the injection of $300 \mathrm{ppm} \mathrm{C}_{2} \mathrm{H}_{2}$ into the air stream at $0.4 \mathrm{~A} \mathrm{~cm}^{-2}$ allow us to distinguish a transition period consisting of two stages before the cell reached a steady state (Fig. 6). During the first stage (first 7-7.5 h), acetylene caused a gradual decrease in voltage. At the same time, the current redistribution behavior was very similar to the case of $0.2 \mathrm{~A} \mathrm{~cm}^{-2}$ (Fig. 3), when inlet segments 1-3 produced lower current than the others. The second stage began as soon as the cell reached a voltage of $\sim 0.65 \mathrm{~V}$ : a rapid decrease of cell potential to $0.130 \mathrm{~V}$ occurred, which was accompanied by additional redistribution of local currents. At the beginning of the second stage, a performance decrease for segments 1-6 to 0 and performance growth for segments 7-10 were detected. When segments 1-6 increased their performances, segments 7-10 decreased, and all segments reached the steady state. Current redistribution at the steady state was $+95 \%$ for segment 10 and $-53 \%$ for segment 1 vs. their initial values.

The spatial fuel cell performance under $\mathrm{C}_{2} \mathrm{H}_{2}$ exposure at $1.0 \mathrm{~A} \mathrm{~cm}^{-2}$ was also characterized by a transition period (Fig. 7). However, the transition period took only $40 \mathrm{~min}$ instead of $8 \mathrm{~h}$ and was similar to the second stage of the previous case. Cell and segments' voltages immediately and rapidly decreased from 0.662 to $0.074 \mathrm{~V}$ under $\mathrm{C}_{2} \mathrm{H}_{2}$ exposure. Simultaneously, the local currents redistributed in much the same way as at $0.4 \mathrm{~A} \mathrm{~cm}^{-2}$. The segments and cell reached the steady state with a local current distribution of $+20 \div-20 \%$.

After changing the cathode gas from a mixture of air and $300 \mathrm{ppm} \mathrm{C}_{2} \mathrm{H}_{2}$ to pure air, the cell and segments' performances recovered. Partial recovery was found for the cell operated at $0.4 \mathrm{~A} \mathrm{~cm}^{-2}$. There was a performance loss after the $\mathrm{C}_{2} \mathrm{H}_{2}$ poisoning test of $65 \mathrm{mV}$, and local currents did not recover their initial values (Fig. 6). In contrast, at $1.0 \mathrm{~A} \mathrm{~cm}^{-2}$, recovery was almost complete: 
the cell voltage was 0.647 vs. the initial value of $0.662 \mathrm{~V}$, and the normalized segments' current densities were close to 1 (Fig. 7).

Spatial EIS data for all ten segments and the total cell during different stages of the contamination test are presented in Figs. 8 and 9 for 0.4 and $1.0 \mathrm{~A} \mathrm{~cm}^{-2}$, respectively. A comparison of the initial EIS data and the data under $\mathrm{C}_{2} \mathrm{H}_{2}$ exposure at $0.4 \mathrm{~A} \mathrm{~cm}^{-2}$ revealed an increase in charge and mass transfer resistances for segments 1-3 after 1-5 h of contaminant exposure, whereas the others did not demonstrate any significant changes (Fig. 8). Additionally, for segments 1 and 2, a drift of impedance values at low frequency was detected, which indicates changes in the segments' impedance during the EIS recording $[75,96]$. Thus, spatial EIS behavior during the first stage of the transition period was very close to the results obtained at 0.1 and $0.2 \mathrm{~A} \mathrm{~cm}^{-2}$ (Fig. 4, 5). After $10 \mathrm{~h}$ of $\mathrm{C}_{2} \mathrm{H}_{2}$ exposure, the segments and the cell were in the steady state, and it was clear that EIS revealed a different behavior pattern. An increase in impedance and the formation of a lowfrequency inductive loop were observed for the cell and segments 1-9. The formation of a lowfrequency negative-resistance loop for segment 10 was previously detected in studies of the impact of CO in hydrogen on PEMFC performance [75] and also during operation at low air stoichiometry $[52,97]$. In this study, the formation of this loop might be explained by several reasons, including the specific impact of $\mathrm{C}_{2} \mathrm{H}_{2}$ and other species originating from acetylene conversion and the depletion of local oxygen concentration at the MEA outlet caused by applied EIS perturbation current. The observation of low-frequency inductance for segments 1-9 might be attributed to the presence of successive electron transfer reactions, relatively slow in comparison with ORR, with the formation of an adsorbed intermediate species on Pt cathode surface [91-94]. Moreover, changes in the localized EIS response indicate changes in the ORR and $\mathrm{C}_{2} \mathrm{H}_{2}$ transformation mechanisms on $\mathrm{Pt}$ with cell voltage and current. Further $\mathrm{C}_{2} \mathrm{H}_{2}$ injection led to a slight increase in impedance for all 
segments. At high current density operation $\left(1.0 \mathrm{~A} \mathrm{~cm}^{-2}\right)$, EIS data also demonstrated a significant increase in impedance response and the appearance of a low-frequency inductive loop for segments 1-9 after $1 \mathrm{~h}$ of $\mathrm{C}_{2} \mathrm{H}_{2}$ exposure (Fig. 9). Segment 10 exhibited a low-frequency negative-resistance loop, and the spatial behavior of all segments was very similar to the previous case.

Recovery with pure air within $1 \mathrm{~h}$ led to a significant decrease in impedance response, with disappearance of low-frequency inductance in both cases (Fig. 8, 9). However, almost full recovery was obtained only at $1.0 \mathrm{~A} \mathrm{~cm}^{-2}$ after $15 \mathrm{~h}$ of operation with air (Fig. 9), whereas even $22 \mathrm{~h}$ of recovery at low current operation $\left(0.4 \mathrm{~A} \mathrm{~cm}^{-2}\right)$ could not provide the initial spatial EIS performance, which confirms the voltage-current data (Fig. 6, 8).

The obtained results allow us to conclude that there are most likely two different mechanisms of $\mathrm{C}_{2} \mathrm{H}_{2}$ transformations/conversions on $\mathrm{Pt}$ depending on the cell potential. At high cell voltage $(>0.65 \mathrm{~V})$, acetylene affects mainly the inlet part of the MEA and quickly transforms into products. At low potentials $(\sim 0.1 \mathrm{~V})$, acetylene is assumed to slowly convert into products and impact all areas of the electrode.

\subsection{Impacts of acetylene on ORR and PEMFC performance}

The electrochemistry of oxygen (its reduction to water and evolution from water) has been intensively studied due to its fundamental complexity and importance for practical application [98]. Oxygen reduction on platinum occurs mainly through a direct 4-electron pathway involving the dissociation of oxygen and its subsequent reduction to water. The mechanism is complicated because of various oxygen reduction intermediates, as well as platinum surface oxides and/or hydroxides; moreover, the reaction involves multiple electron transfers and elemental steps. 
$\mathrm{O}_{2}+4 \mathrm{e}^{-}+4 \mathrm{H}^{+} \rightarrow 2 \mathrm{H}_{2} \mathrm{O} \quad \mathrm{E}_{0}=1.229 \mathrm{~V}$ vs. SHE (standard hydrogen electrode)

The direct 4-electron reduction requires the dissociation of oxygen; however, its dissociation energy is quite large $\left(498.3 \mathrm{~kJ} \mathrm{~mol}^{-1}\right)$ because the bond between $\mathrm{Pt}$ and $\mathrm{O}$ is very strong. The more energetically favorable path is the superoxo/peroxo path, with transfer of the electron to the $\mathrm{O}_{2}$. The dissociation energy of $\mathrm{O}_{2}^{-}$and/or $\mathrm{O}_{2}{ }^{2-}$ is much lower than the dissociation energy of $\mathrm{O}_{2}$ $\left(98.7 \mathrm{~kJ} \mathrm{~mol}^{-1}\right)$, resulting in an easier reaction path without a strong interaction with the catalyst [99]. Moreover, it was found that $\mathrm{O}_{2}$ adsorption predominantly occurs in parallel to the Pt surface, in a bridge configuration between two Pt atoms. After accepting electrons from electrode to the $\pi^{*}$ antibonding orbital, the chemosorbed species dissociates to atomic oxygen sitting at three-fold hollow sites $[98,100]$.

On the other hand, oxygen can also be reduced by a series of 2-electron reactions with the formation of hydrogen peroxide, which can be a final product or an intermediate leading to water.

$\mathrm{O}_{2}+2 \mathrm{e}^{-}+2 \mathrm{H}^{+} \rightarrow \mathrm{H}_{2} \mathrm{O}_{2} \quad \mathrm{E}_{0}=0.67$ V vs. SHE

$\mathrm{H}_{2} \mathrm{O}_{2}+2 \mathrm{e}^{-}+2 \mathrm{H}^{+} \rightarrow \mathrm{H}_{2} \mathrm{O} \quad \mathrm{E}_{0}=1.77 \mathrm{~V}$ vs. SHE

To obtain maximum efficiency and avoid corrosion in PEMFC, it is necessary to achieve 4-electron reduction, whereas 2-electron reduction is unwanted due to peroxide formation and possible Nafion degradation. The direct 4-electron mechanism mainly occurs on a clean Pt surface.

The first step of $\mathrm{C}_{2} \mathrm{H}_{2}$ adsorption on $\mathrm{Pt}$ (111) most likely includes the formation of distorted $\mathrm{C}_{2} \mathrm{H}_{2}$ species on triangular sites (fcc 3-fold hollow site on $\mathrm{Pt}(111)$ ) with the $\mathrm{C}-\mathrm{C}$ axis parallel to the metal surface and the C-C-H plane tilted relative to the surface normal [101-104] (Fig. 10 a). This bonding accompanies $\pi$ donation to the surface and surface back-donation to acetylene $\pi^{*}$, giving rise to ethylenic-like $\sigma$ bonding orbitals between $\mathrm{C}_{2} \mathrm{H}_{2}$ and $\mathrm{Pt}[104,105]$. Thus, the adsorption of 
acetylene is non-dissociative $[106,107]$. The distorted $\mathrm{C}_{2} \mathrm{H}_{2}$ surface species subsequently rearrange to vinylidene structures $\left(\eta^{2}-\mu_{3}-\mathrm{CCH}_{2}\right)$ (Fig. $10 \mathrm{~b}$ ), which are characterized by the $\mathrm{C}-\mathrm{C}$ backbone tilted up from the metal surface (angle $\sim 30^{\circ}$ ) [101, 102, 108-110]. At temperatures of 200-380 K, a variety of different species are usually formed that include ethylidene $\left(\mathrm{M}=\mathrm{CHCH}_{3}\right)$, di- $\sigma$-bonded ethylene $\left(\mathrm{M}-\mathrm{CH}_{2} \mathrm{CH}_{2}-\mathrm{M}\right)$, $\mu$-vinylidene $\left(\mathrm{M}=\mathrm{CCH}_{2}\right)$ and ethylidyne $\left(\mathrm{M} \equiv \mathrm{CCH}_{3}\right) \quad[101,108,109]$ (Fig. 10). The number of $\mathrm{Pt}$ sites obscured by the one adsorbed molecule of $\mathrm{C}_{2} \mathrm{H}_{2}$ varies from 2 [43, 107] to 3.5 [111].

Thus, the adsorption of $\mathrm{C}_{2} \mathrm{H}_{2}$ results in the redistribution of electronic density between the catalyst and adsorbants and modification of the geometric properties of the catalytic particles (a decrease of available Pt sites for ORR). RRDE studies confirm these assumptions and provide valuable information about the electrochemical conversions of $\mathrm{C}_{2} \mathrm{H}_{2}$. $\mathrm{CV}$ measurements show that the first positive potential scan exhibited the complete absence of hydrogen electro-oxidation [37, 107]. Moreover, studies of $\mathrm{C}_{2} \mathrm{H}_{2}$ adsorption on $\mathrm{Pt}$ at 1.0-3.0 V revealed that acetylene partially substituted chemisorbed oxygen [112] and most likely water at low operating potentials [104]. This result indicates that the Pt surface is covered by $\mathrm{C}_{2} \mathrm{H}_{2}$, which decreases the available ECA for ORR. In addition, there is an increase in hydrogen peroxide formation during ORR in the presence of acetylene [37], which is similar to the effect of many other impurities [11, 13, 23, 31, 38, 39, 99, 113]. This observation may suggest that adsorbed $\mathrm{C}_{2} \mathrm{H}_{2}$ decreases the concentration of empty and appropriate Pt-pair sites required for the dissociation of the $\mathrm{O}_{2}$ bond, so the ORR proceeds partially through the 2-electron pathway [99]. In terms of fuel cell performance, all these findings can explain a decrease in performance and an increase in charge and mass transfer resistances. 
Adsorbed acetylene on Pt cathode under fuel cell operating conditions can transform by both chemical and electrochemical mechanisms, and it is very important to understand the processes to develop mitigation procedures. It has been found that under RRDE conditions at potentials less than $0.2 \mathrm{~V}$, acetylene is reduced to ethylene and ethane [107, 111, 114], whereas at potentials greater than $0.35 \mathrm{~V}$ it is oxidized to $\mathrm{CO}_{2}[43,107,111]$. Thus, the impacts of $\mathrm{C}_{2} \mathrm{H}_{2}$ on fuel cell performance should be considered depending on the operating potential of the cell.

At low current density or high potential $(>0.65 \mathrm{~V})$ and under fuel cell operating conditions, there is an electrochemical and chemical oxidation of acetylene with almost full conversion of $\mathrm{C}_{2} \mathrm{H}_{2}$ to $\mathrm{CO}_{2}$ [34]. For electrochemical oxidation, the observed negative pressure dependence indicates that the rate-determining step involves a species other than acetylene. Moreover, the Tafel slope of $R T / F$ suggests a reaction following the first transfer step at low coverage, or following any charge transfer step at full coverage. For full coverage, no pressure dependence would be expected. It should be mentioned that for the electrochemical pathway, water discharge is required, and the reaction mechanism can be formulated as $[41,43,107,115]$ :

$\mathrm{C}_{2} \mathrm{H}_{2}+[] \leftrightarrow\left[\mathrm{C}_{2} \mathrm{H}_{2}\right]$,

where $\left[\mathrm{C}_{2} \mathrm{H}_{2}\right]$ is most likely some $\eta^{2}-\mu_{3}-\mathrm{CCH}_{2}$ species.

$\mathrm{H}_{2} \mathrm{O}+[] \leftrightarrow[\mathrm{OH}]+\mathrm{H}^{+}+\mathrm{e}^{-}$

$\left[\mathrm{C}_{2} \mathrm{H}_{2}\right]+[\mathrm{OH}] \rightarrow$ intermediates $\quad$ (rate-determining step)

intermediates $+\mathrm{H}_{2} \mathrm{O} \rightarrow \ldots \rightarrow \mathrm{CO}_{2}+\mathrm{H}^{+}+\mathrm{e}^{-}+[]$

It is proposed that the rate determining step involves single electron transfer and might proceed through the deprotonation of adsorbed acetylene [107]:

$\left[\mathrm{C}_{2} \mathrm{H}_{2}\right]+[\mathrm{OH}] \rightarrow\left[\mathrm{C}_{2} \mathrm{H}\right]+\mathrm{H}_{2} \mathrm{O}+[]$ 
$\left[\mathrm{C}_{2} \mathrm{H}_{2}\right] \rightarrow\left[\mathrm{C}_{2} \mathrm{H}\right]+\mathrm{H}^{+}+\mathrm{e}^{-}$

or through the formation of adsorbed oxygenated acetylene species:

$\left[\mathrm{C}_{2} \mathrm{H}_{2}\right]+[\mathrm{OH}] \rightarrow\left[\mathrm{C}_{2} \mathrm{HOH}\right]+\mathrm{H}^{+}+\mathrm{e}^{-}$

$\left[\mathrm{C}_{2} \mathrm{H}_{2}\right]+[\mathrm{OH}] \rightarrow\left[\mathrm{C}_{2} \mathrm{H}_{2} \mathrm{OH}\right]$

Studies of acetylene chemical oxidation on Pt revealed controversial conclusions about the mechanism. Previously, it was shown that the first step of oxidation at $1000 \mathrm{~K}$ is the activation of C-H bonds. Surface carbon can then react with adsorbed atomic oxygen to form CO, which then either desorbs or oxidizes further to $\mathrm{CO}_{2}$ [116]. In a temperature-programmed desorption study of coadsorbed atomic oxygen and acetylene, it was determined that acetylene oxidation proceeds through an intermediate with the stoichiometry $\mathrm{C}: \mathrm{H}=1: 1$, suggesting that acetylene is oxidized as $\mathrm{C}_{2} \mathrm{H}_{2}$ [117]. Recently, it was shown that during acetylene oxidation, $\eta^{2}-\mu_{3}-\mathrm{CCH}_{2}$ species and atomic oxygen are the primary intermediates involved in the reaction. Moreover, it is proposed that acetylene oxidation occurs in a single step at 330-420 K when oxydehydrogenation and skeletal oxidation proceed simultaneously [110]. Schematically, the chemical oxidation of acetylene might be presented by the following reactions:

$\mathrm{C}_{2} \mathrm{H}_{2}+[] \leftrightarrow\left[\mathrm{C}_{2} \mathrm{H}_{2}\right]$

$\mathrm{O}_{2}+[] \leftrightarrow\left[\mathrm{O}_{2}\right]$

$\left[\mathrm{O}_{2}\right] \rightarrow 2[\mathrm{O}]$

$\left[\mathrm{C}_{2} \mathrm{H}_{2}\right]+[\mathrm{O}] \rightarrow \ldots \rightarrow \mathrm{CO}_{2}+\mathrm{H}_{2} \mathrm{O}+[]$

In the operating conditions of the fuel cell cathode at low current density, it is reasonable to assume that the chemical oxidation of adsorbed $\eta^{2}-\mu_{3}-\mathrm{CCH}_{2}$ species by atomic oxygen occurs together with electrochemical oxidation. 
The spatial EIS data and current distribution obtained at low overall current density operation demonstrated that only the inlet part of MEA (segments 1-4) is affected by acetylene, whereas the outlet segments are not poisoned by the contaminant (Fig. 2-5). This observation allows us to conclude that at high potential $(>0.65 \mathrm{~V})$ and under fuel cell operating conditions (e.g., Pt cathode, $80^{\circ} \mathrm{C}$ ), acetylene adsorption and its further chemical and electrochemical oxidation occur relatively fast in comparison with ORR.

As soon as the cell voltage reached $0.65 \mathrm{~V}$, it became obvious that there was a change in the mechanism of acetylene transformation (Fig. 6). Moreover, there was a decrease in acetylene conversion to $\sim 50 \%$ at a cell voltage of $0.67 \mathrm{~V}$ and no conversion at $0.55 \mathrm{~V}$ [34]. Later, S. Gilman studied the coverage of the Pt electrode surface by acetylene at different potentials using the multipulse potentiodynamic method [111]. Maximum surface coverage ( 80\%) was observed at electrode potentials of $0.2-0.4 \mathrm{~V}$, and the decrease in coverage at high and low potentials was explained by $\mathrm{C}_{2} \mathrm{H}_{2}$ oxidation and reduction, respectively, which was also confirmed by $\mathrm{CV}$ results $[37,107]$. The lack of any acetylene conversion at cell voltages of $0.55 \mathrm{~V}$ and lower was shown in [34], confirming our assumption about acetylene coverage on Pt. Previously, T.M. Beloslyudova and D.V. Sokol'skii showed that the adsorption of acetylene on a platinum surface at $0.6 \mathrm{~V}$ resulted in a potential decrease of $0.35 \mathrm{~V}$ and hydrogen evolution [118]. The authors explained observations by the possible dehydrogenation of acetylene and formation of carbon deposits. Thus, at this range of electrode potential, $0.6-0.2 \mathrm{~V}$, there are no acetylene electrochemical reactions: acetylene adsorbs on the Pt surface and affects the whole electrode area, decreasing the cell voltage (Fig. 6, 7). In addition, the observed current density redistribution accompanying a voltage drop can be explained by fast and strong acetylene adsorption, when acetylene occupies all available Pt sites. Moreover, 
the strong $\mathrm{C}_{2} \mathrm{H}_{2}$ adsorption is confirmed by DFT calculations, which showed that the adsorption energy of $\mathrm{C}_{2} \mathrm{H}_{2}$ on $\mathrm{Pt}$ (111) varies from 67.8 to $209 \mathrm{~kJ} \mathrm{~mol}^{-1}$ depending on the adsorbate's structure [119], whereas for $\mathrm{O}_{2}$ it is in the range of $16.4-37.6 \mathrm{~kJ} \mathrm{~mol}^{-1}$ [120]. As soon as the Pt surface is covered by acetylene and cell voltage is as low as $\sim 0.1 \mathrm{~V}$, electroreduction of the adsorbed acetylene occurs with the formation of $\mathrm{C}_{2} \mathrm{H}_{4}$ and $\mathrm{C}_{2} \mathrm{H}_{6}$. Later, the products of reduction desorb and free the Pt surface, leading to the steady state of the segments and cell.

As mentioned previously, the electrochemical reduction of $\mathrm{C}_{2} \mathrm{H}_{2}$ under the conditions of a rotating disk electrode $(\mathrm{RDE})$ or RRDE occurs at low electrode potentials $(<0.2 \mathrm{~V})$ with the formation of ethylene and ethane $[106,114,118,121]$. It was mentioned that the limiting rate of acetylene reduction corresponds to the maximum rate at which acetylene can diffuse to the electrode in an electrolyte solution [121]. Thus, the electrochemical reduction of acetylene in RRDE is characterized by a high reaction rate constant, and acetylene adsorption and diffusion are most likely rate-determining processes $[106,121]$. However, the detailed studies of electrochemical $\mathrm{C}_{2} \mathrm{H}_{2}$ hydrogenation demonstrated a negative effect of acetylene partial pressure, indicating that neither acetylene nor any intermediates derived from it could be involved in the rate-determining step [114]. It was suggested that the rates of acetylene hydrogenation are limited by the supply of electrically discharged hydrogen ions at 0.05-0.2 V. The authors proposed the following mechanism of $\mathrm{C}_{2} \mathrm{H}_{2}$ electroreduction:

$\mathrm{C}_{2} \mathrm{H}_{2}+[] \leftrightarrow\left[\mathrm{C}_{2} \mathrm{H}_{2}\right]$

[]$+\mathrm{H}^{+}+\mathrm{e}^{-} \leftrightarrow[\mathrm{H}]$

$\left[\mathrm{C}_{2} \mathrm{H}_{2}\right]+[\mathrm{H}] \leftrightarrow\left[\mathrm{C}_{2} \mathrm{H}_{3}\right]+[]$

$\left[\mathrm{C}_{2} \mathrm{H}_{3}\right]+[\mathrm{H}] \leftrightarrow\left[\mathrm{C}_{2} \mathrm{H}_{4}\right]+[]$ 
It should be noted that together with the acetylene electroreduction, there is oxygen reduction, and both processes require protons and free Pt surface. The higher rate of ORR in the conditions of the operating fuel cell enables oxygen to compete more favorably for hydrogen and suitable Pt surface sites. The observed low-frequency inductance in spatial EIS recorded at high current density operation (Fig. 8, 9) requires explanation with respect to its mechanistic meaning. Inductance implies that the current signal follows a perturbation with a significant phase delay, which can be rationalized by assuming slowness of $\left[\mathrm{C}_{2} \mathrm{H}_{2}\right]$ coverage relaxation: the acetylene coverage decreases with increasing perturbation current signal, but it takes some time before new steady state coverage is established and the corresponding current flows [91-94, 122]. This phase delay causes the observed low-frequency inductance, indicating that the acetylene electrochemical reduction is most likely a slow process in comparison with oxygen reduction at the given conditions. Previous experimental and theoretical studies confirmed this assumption and showed that the activation energy for ORR on $\mathrm{Pt}$ is in the range of 24 to $77.2 \mathrm{~kJ} \mathrm{~mol}^{-1}$ [120,123-125], which is lower than the activation energy for the hydrogenation of acetylene $\left(108-115 \mathrm{~kJ} \mathrm{~mol}^{-1}\right)$ [119].

\subsection{Effect of $\mathrm{C}_{2} \mathrm{H}_{2}$ exposure on fuel cell performance and ECA after recovery}

A comparison of initial ECA values for MEAs samples showed that ECAs varied. The anode surface area was in the range of $67-85 \mathrm{~m}^{2} \mathrm{~g}^{-1}$ whereas for the cathode, the surface area range was $69-81 \mathrm{~m}^{2} \mathrm{~g}^{-1}$. However, the initial performance of the MEAs was close, cell voltage varied from 0.650 to $0.670 \mathrm{~V}$ at total current density of $1.0 \mathrm{~A} \mathrm{~cm}^{-2}$. The distributions of the anode and cathode ECA differences are presented in Fig. 11. The ECA difference was calculated between values after (EOT) and before (BOT) $\mathrm{C}_{2} \mathrm{H}_{2}$ exposure. The evolution of ECA after the contamination tests indicated that the anode and cathode losses were in the range of $0-12.2 \%$ and $1-21.6 \%$, respectively. Observations showed that the anode ECA was affected less than the cathode ECA. Operation at 
$0.1 \mathrm{~A} \mathrm{~cm}^{-2}$ resulted in the most significant ECA losses of 12.2 and $21.6 \%$ for anode and cathode, respectively (Table 2). The ECA decrease and noticeable catalyst degradation observed at 0.1$0.4 \mathrm{~A} \mathrm{~cm}^{-2}$ could be attributed to the impact of impurity as well as low current operation. Acetylene exposure at $0.6-1.0 \mathrm{~A} \mathrm{~cm}^{-2}$ led to cathode ECA loss of 9-14.4\%, which is typically observed for a fuel cell operated without any impurities in an air stream. Thus, this loss might be associated with the degradation processes, and ECA was not seriously affected by $\mathrm{C}_{2} \mathrm{H}_{2}$. After the acetylene contamination tests, there was no pinhole formation in the MEA, and the overall hydrogen crossover current varied from 1.31 to $1.49 \mathrm{~mA} \mathrm{~cm}^{-2}$ for different MEA samples.

Fig. 12 presents the distributions of voltage differences between the values after (EOT) and before the contamination test (BOT) at fixed current densities as functions of the segment locations. The acetylene exposure test at $0.1 \mathrm{~A} \mathrm{~cm}^{-2}$ resulted in a spatial performance loss of $30 \mathrm{mV}$ obtained at low current density operation. However, the performance loss was reduced with increasing the operating current. The spatial fuel cell performances before and after $\mathrm{C}_{2} \mathrm{H}_{2}$ exposure were analyzed in terms of activation, ohmic and mass transfer overpotentials as described in the Experimental section and reference [57] (Table 2). The data revealed that the performance loss at low current density is caused by increased activation overpotential due to a decreased ECA. A slight performance improvement $(\sim 25-30 \mathrm{mV})$ was found after the contamination test at $0.2 \mathrm{~A} \mathrm{~cm}^{-2}$ because of reduced mass transfer overpotentials. A comparison of the curves for the cases of 0.4 and $0.6 \mathrm{~A} \mathrm{~cm}^{-2}$ revealed non-uniform performance degradation during the contamination test, resulting in performance decreases of $50 \mathrm{mV}$ for the inlet part of MEA, whereas the outlet demonstrated a higher performance. Under these conditions, the performance loss is explained by increased activation and mass transfer overpotentials. The most interesting observation was the lack of any significant performance losses after acetylene exposure at $1.0 \mathrm{~A} \mathrm{~cm}^{-2}$. 
The observed voltage losses of the samples can be attributed to both the impact of the contaminant and other fuel cell degradation mechanismss. However, it is currently difficult to separate these two types of contributions. Operation at a low current density of $0.1-0.4 \mathrm{~A} \mathrm{~cm}^{-2}$, where ORR kinetics control the reaction rate, usually affects the ECA and results in an activation overpotential increase. At high currents, electrode and gas diffusion layer (GDL) degradation due to water production and removal of PTFE is also present [126]. It is assumed that $\mathrm{C}_{2} \mathrm{H}_{2}$ could facilitate degradation under certain conditions. For instance, it was shown that acetylene shifts the ORR mechanism from a 4 to a 2-electron path and causes an increase in $\mathrm{H}_{2} \mathrm{O}_{2}$ production $[38,43]$. Peroxide decomposes the ionomer in the membrane and catalyst layer, which results in a reduction of the ECA and modification of hydrophilic/hydrophobic properties of the catalyst layer. An increase in activation overpotential for tests at $0.1,0.4$ and $0.6 \mathrm{~A} \mathrm{~cm}^{-2}$ was observed. However, the most substantial effect was found at $0.1 \mathrm{~A} \mathrm{~cm}^{-2}$. It is also assumed that acetylene impact could disrupt mass transport by locally increasing the oxygen flux and decreasing the oxygen concentration at the catalyst surface due to the ECA decrease. This situation is similar to the mass transport loss observed with a decrease in catalyst loading [127]. The impact of mass transfer losses was revealed for 0.4 and 0.6 A cm${ }^{-2}$ cases, whereas for $1.0 \mathrm{~A} \mathrm{~cm}^{-2}$ a noticeable effect was not found. The introduction of $\mathrm{C}_{2} \mathrm{H}_{2}$ at $1.0 \mathrm{~A} \mathrm{~cm}^{-2}$ results in the lowest cell voltage of $0.07 \mathrm{~V}$, which most likely leads to a faster acetylene reduction, a low production level of peroxide and a low catalyst coverage by acetylene. It is likely that the exceptional $0.2 \mathrm{~A} \mathrm{~cm}^{-2}$ results are exclusively ascribed to the operating conditions, peculiarities of $\mathrm{C}_{2} \mathrm{H}_{2}$ impact under these operating parameters and some certain properties of the MEA. Thus, the operation of a fuel cell at low current under $\mathrm{C}_{2} \mathrm{H}_{2}$ exposure leads to nonhomogeneous performance degradation, whereas high current can likely mitigate the negative impact of the contaminant and prevent degradation. 


\section{Conclusions}

The spatial performance of a PEMFC exposed to $300 \mathrm{ppm} \mathrm{C}_{2} \mathrm{H}_{2}$ was studied using a segmented cell system at different operating currents. Acetylene exposure caused a cell performance decrease of $20-50 \mathrm{mV}$ at $0.1-0.2 \mathrm{~A} \mathrm{~cm}^{-2}$ and $590-620 \mathrm{mV}$ at $0.4-1.0 \mathrm{~A} \mathrm{~cm}^{-2}$. The voltage decrease was accompanied by significant changes in the current density distribution.

At low current operation, localized performance was rapidly redistributed immediately after $\mathrm{C}_{2} \mathrm{H}_{2}$ injection. Inlet segments 1-4 showed a decrease in performance due to the impact of $\mathrm{C}_{2} \mathrm{H}_{2}$, whereas the downstream segments demonstrated an increase in current. The observed spatial performance can be attributed to acetylene adsorption and its chemical and electrochemical oxidations to $\mathrm{CO}_{2}$, which are likely fast and occur mostly at the inlet part of the cell.

As soon as the cell reached a voltage of $0.55-0.6 \mathrm{~V}$ under acetylene exposure at $0.4-1.0 \mathrm{~A} \mathrm{~cm}^{-2}$, there was a drastic redistribution of the localized currents simultaneously with a sharp voltage decrease to $0.07-0.13 \mathrm{~V}$. This redistribution can be explained the lack of electrochemical acetylene reactions at potentials of $0.6-0.2 \mathrm{~V}$, which allows fast and strong $\mathrm{C}_{2} \mathrm{H}_{2}$ adsorption to occur, so that acetylene occupies all available Pt sites at the electrode. As soon as the Pt surface is covered by acetylene and the cell voltage is low as $\sim 0.1 \mathrm{~V}, \mathrm{C}_{2} \mathrm{H}_{2}$ electroreduction begins the formation of $\mathrm{C}_{2} \mathrm{H}_{4}$ and $\mathrm{C}_{2} \mathrm{H}_{6}$. At steady state, the inlet segments produced less current than the outlet segments. Acetylene electroreduction occurs together with oxygen reduction, and both processes require protons/hydrogen and free Pt surface. The higher rate of ORR under the conditions of the operating fuel cell enables oxygen to compete more favorably for hydrogen and the Pt surface. The observed low-frequency inductance in spatial EIS recorded at high current density operation allows us to 
assume that acetylene electrochemical reduction is most likely slow in comparison with oxygen reduction under the given operating conditions.

A partial recovery of the cell voltage was observed after stopping the $\mathrm{C}_{2} \mathrm{H}_{2}$ injection at 0.1$0.6 \mathrm{~A} \mathrm{~cm}^{-2}$, and full recovery was reached at $1.0 \mathrm{~A} \mathrm{~cm}^{-2}$. Analysis of the spatial performance and ECA before and after the acetylene exposure tests showed that at low current operation (except $\left.0.2 \mathrm{~A} \mathrm{~cm}^{-2}\right)$, there was non-homogeneous performance loss $(\sim 50 \mathrm{mV})$, whereas high current can likely mitigate the negative impact of the contaminant and prevent degradation.

\section{Acknowledgments}

The authors gratefully acknowledge the Department of Energy (DE-EE0000467) and Office of Naval Research (N00014-11-1-0391) for funding this work. The authors also thank Günter Randolf and Keith Bethune for their valuable support regarding the system operation as well as Kevin Davies for discussions of the results. The authors are grateful to the Hawaiian Electric Company for their ongoing support of the operations of the Hawaii Sustainable Energy Research Facility.

\section{References}

[1] J.M. Moore, P.L. Adcock, J.B. Lakeman, G.O. Mepsted, The effects of battlefield contaminants on PEMFC performance, J. Power Sources 85 (2000) 254.

[2] G. Mepsted, Investigation of the effects of air contaminants of SPFC performance, ETSU F/02/00172REP, DTI/Pub URN 01/905, UK Department of Trade and Industry, UK, 2001. 
[3] X. Chen, Z. Shi, N. Glass, L. Zhang, J. Zhang, D. Song, Z.-S. Liu, H. Wang, J. Shen, A review of PEM hydrogen fuel cell contamination: Impacts, mechanisms, and mitigation, J. Power Sources 165 (2007) 739.

[4] J. St-Pierre, Air impurities, in: N. Büchi, M. Inaba, T.J. Schmidt (Eds.), Polymer Electrolyte Fuel Cell Durability, Springer, New York, 2009, p. 289.

[5] N. Zamel, X. Li, Effect of contaminants on polymer electrolyte membrane fuel cells, Prog. Energy Combust. Sci. 37 (2011) 292.

[6] Y. Nagahara, S. Sugawara, K. Shinohara, The impact of air contaminants on PEMFC performance, J. Power Sources 182 (2008) 422.

[7] S. Imabayashi, Y. Kondo, R. Komori, A. Kawano, T. Ohsaka, Effects of atmospheric trace species on the oxygen reduction reaction on the production of $\mathrm{H}_{2} \mathrm{O}_{2}$, ECS Trans. 16 (2008) 925.

[8] D. Imamura, E. Yamaguchi, Effect of air contaminants on electrolyte degradation in PEMFC, ECS Trans. 25 (2009) 813.

[9] F. Jing, M. Hou, W. Shi, J. Fu, H. Yu, P. Ming, B. Yi, The effect of ambient contamination on PEMFC performance, J. Power Sources 166 (2007) 172.

[10] R. Mohtadi, W.-K. Lee, J.W. Van Zee, Assessing durability of cathodes exposed to common air impurities, J. Power Sources 138 (2004) 216.

[11] F.H. Garzon, F.A. Uribe, Effects of contaminants of catalyst activity, in: W. Vielstich, H.A. Gasteiger, A. Lamm, H. Yokokawa (Eds.), Handbook of Fuel Cells - Fundamentals, Technology and Applications, vol. 5. Advances in electrocatalysis, materials, diagnostics and durability, John Wiley \& Sons, 2010. 
[12] F.H. Garzon, T. Lopes, T. Rockward, J.-M. Sansiñena, B. Kienitz, R. Mukundan, T. Springer, The impact of impurities on long term PEMFC performance, ECS Trans. 25 (2009) 1575.

[13] Y. Garsany, O.A. Baturina, K.E. Swider-Lyons, Impact of $\mathrm{SO}_{2}$ on the oxygen reduction reaction at Pt/Vulcan carbon electrocatalysts, J. Electrochem. Soc. 154 (2007) B670.

[14] B.D. Gould, O.A. Baturina, K.E. Swider-Lyons, Deactivation of Pt/VC PEMFC cathodes by $\mathrm{SO}_{2}, \mathrm{H}_{2} \mathrm{~S}$ and COS, J. Power Sources 188 (2009) 89.

[15] O.A. Baturina, B.D. Gould, Y. Garsany, K.E. Swider-Lyons, Insights on the $\mathrm{SO}_{2}$ poisonin of $\mathrm{Pt}_{3} \mathrm{CO} / \mathrm{VC}$ and Pt/VC fuel cell catalysts, Electrochim. Acta 55 (2010) 6676.

[16] S. Tsushima, K. Kaneko, H. Morioka, S. Harai, Influence of $\mathrm{SO}_{2}$ concentration and relative humidity on electrode poisoning in PEMFC, J. Therm. Sci. Technol. 7 (2012) 619.

[17] M.M. Saleh, M.I. Awad, F. Kitamura, T. Ohsaka, Sulphur dioxide poisoning and recovery of Pt nanoparticles: Effect of particle size, Int. J. Electrochem. Sci. 7 (2012) 12004.

[18] J. Zhai, M. Hou, H. Zhang, Z. Zhou, J. Fu, Z. Shao, B. Yi, Study of $\mathrm{SO}_{2}$ crossover in PEMFC, J. Power Sources 196 (2011) 3172.

[19] Y. Zhai, G. Bender, S. Dorn, R. Rocheleau, The multiprocess degradation of PEMFC performance due to $\mathrm{SO}_{2}$ contamination and its recovery, J. Electrochem. Soc. 157 (2010) B20.

[20] Y. Zhai, K. Bethune, G. Bender, R. Rocheleau, Analysis of the $\mathrm{SO}_{2}$ contamination effect on the oxygen reduction reaction in PEMFCs by EIS, J. Electrochem. Soc. 159 (2012) B524.

[21] J. St-Pierre, N. Jia, R. Rahmani, PEMFC contamination model: Competitive adsorption demonstrated with $\mathrm{NO}_{2}$, J. Electrochem. Soc. 155 (2008) B315.

[22] M. Cheng, J. Zhang, P. Wang, T. Zhu, Effect, mechanism and recovery of $\mathrm{NO}_{\mathrm{x}}$ poisoning on oxygen reduction reaction at Pt/C catalysts, J. Power Sources 196 (2011) 620. 
[23] T. Lopes, J. Chlistunoff, J.-M. Sansiñena, F.H. Garzon, Oxygen reduction reaction on $\mathrm{Pt} /$ carbon fuel cell catalyst in the presence of trace quantities of ammonium ions: An RRDE study, Int. J. Hydrogen Energy 37 (2012) 5202.

[24] T. Lopes, D.-S. Kim, Y-S. Kim, F.H. Garzon, Ionic transport and water vapor uptake of ammonium exchange perfluorosulfonic acid membranes, J. Electrochem. Soc. 159 (2012) B265.

[25] X.-Z. Yuan, H. Li, Y. Yu, M. Jiang, W. Qian, S. Zhang, H. Wang, S. Wessel, T.T.H. Cheng, Diagnosis of contamination introduced by ammonia at the cathode in a PEMFC, Int. J. Hydrogen Energy 37 (2012) 12464.

[26] M.S. Mikkola, T. Rockward, F.A. Uribe, B.S. Pivovar, The effect of $\mathrm{NaCl}$ in the cathode air stream on PEMFC performance, Fuel Cells 7 (2007) 153.

[27] D. Imamura, K.Ohno, Impact of $\mathrm{Na}^{+}$and $\mathrm{Cl}^{-}$on degradation of PEMFC, LRD25-49, Fuel Cell Seminar 2009, November 16-19, 2009, Palm Springs, CA, USA.

[28] P. Faber, F. Drewnick, J. Piske, T. Kurz, S. Borrmann, Effects of atmospheric aerosol on the performance of environmentally sustainable passive air-breathing PEM fuel cells, Int. J. Hydrogen Energy 37 (2012) 17203.

[29] H. Li, J. Zhang, K. Fatih, Z. Wang, Y. Tang, Z. Shi, S. Wu, D. Song, J. Zhang, N. Jia, S. Wessel, R. Abouatallah, N. Joos, PEMFC contamination: Testing and diagnosis of tolueneinduced cathode degradation, J. Power Sources 185 (2008) 272.

[30] H. Li, J. Zhang, Z. Shi, D. Song, K. Fatih, S. Wu, H. Wang, J. Zhang, N. Jia, S. Wessel, R. Abouatallah, N. Joos, PEM fuel cell contamination: Effects of operating conditions on toluene-induced cathode degradation, J. Electrochem. Soc. 156 (2009) B252. 
[31] M.S. El-Deab, F. Kitamura, T. Ohsaka, Poisoning effect of selected hydrocarbon impurities on the catalytic performance of $\mathrm{Pt} / \mathrm{C}$ catalysts towards the oxygen reduction reaction, $\mathrm{J}$. Electrochem. Soc. 160 (2013) F651.

[32] J. St-Pierre, Y. Zhai, M. Angelo, Quantitative ranking criteria for PEMFC contaminants, Int. J. Hydrogen Energy 37 (2012) 6784.

[33] Y. Zhai, J. St-Pierre, M. Angelo, The impact of operating conditions on the performance effect of selected airborne PEMFC contaminants, ECS Trans. 50 (2012) 635.

[34] Y. Zhai, J. St-Pierre, J. Ge, PEMFC cathode contamination with $\mathrm{C}_{2} \mathrm{H}_{2}$ - potential dependency, ECS Trans. 58 (2013) 507.

[35] J. St-Pierre, M.B.V. Virji, Cell performance in a PEMFC stack during contamination, ECS Trans. 58 (2013) 555.

[36] J. St-Pierre, J. Ge, Y. Zhai, T.V. Reshetenko, M. Angelo, PEMFC cathode contamination mechanisms for several VOCs - acetonitrile, acetylene, bromomethane, iso-propanol, methyl methacrylate, naphthalene and propene, ECS Trans. 58 (2013) 519.

[37] J. Ge, J. St-Pierre, Y. Zhai, PEMFC cathode catalyst contamination evaluation with a RRDE Acetylene, Electrochim. Acta 133 (2014) 65.

[38] J. Ge, J. St-Pierre, Y. Zhai, PEMFC cathode catalyst contamination evaluation with a RRDE - Acetonitrile, Electrochim. Acta 134 (2014) 272.

[39] J. Ge, J. St-Pierre, Y. Zhai, PEMFC cathode catalyst contamination evaluation with a RRDE Propene and Naphthalene, Electrochim. Acta 138 (2014) 437.

[40] L. Lloyd, Handbook of industrial catalysts, Springer, New York (2011).

[41] O.A. Petrii, Electrochemical oxidation of organic compound at metals of the platinum group, Progress of electrochemistry of organic compounds 1 (1971) 319. 
[42] O.A. Petrii, Oxidation of $\mathrm{C}_{2}$ molecules, in: W. Vielstich, H.A. Gasteiger, A. Lamm, (Eds.), Handbook of Fuel Cells - Fundamentals, Technology and Applications, vol. 2. Electrocatalysis, John Wiley \& Sons, 2003, p. 662 (Chapter 45).

[43] J.W. Johnson, H. Wroblowa, J.O'M. Bockris, The mechanism of the electro-oxidation of acetylene on platinum, J. Electrochem. Soc. 111 (1964) 863.

[44] L.C. Pérez, L. Brandão, J.M. Sousa, A. Mendes, Segmented polymer electrolyte membrane fuel cells - A review, Renewable and Sustainable Energy Reviews 15 (2011) 169.

[45] S. Cleghorn, C.R. Derouin, M.S. Wilson, S. Gottesfeld, A printed circuit board approach to measuring current distribution in a fuel cell, J. Appl. Electrochem. 28 (1998) 663.

[46] J. Stumper, S.A. Campbell, D.P. Wilkinson, M.C. Johnson, M. Davis, In-situ methods for the determination of current distributions in PEM fuel cells, Electrochim. Acta 43 (1998) 3773.

[47] M. Noponen, T. Mennola, M. Mikkola, T. Hottinen, P. Lund, Measurement of current distribution in a free-breathing PEMFC, J. Power Sources 106 (2002) 304.

[48] J.J. Hwnag, W.R. Chang, R.G. Peng, P.Y. Chen, A. Su, Experimental and numerical studies of local current mapping on a PEM fuel cell, Int. J. Hydrogen Energy 33 (2008) 5718.

[49] Y.-G. Yoon, W.-Y. Lee, T.-H. Yang, G.-G. Park, Ch.-S. Kim, Current distribution in a single cell of PEMFC, J. Power Sources 118 (2003) 193.

[50] F.N. Büchi, A.B. Geiger, R.P. Neto, Dependance of current distribution on water management in PEFC of technical size, J. Power Sources 145 (2005) 62.

[51] F.-B. Weng, B.-Sh. Jou, Ch.-W. Li, A. Su, Sh.-H. Chan, The effect of low humidity on the uniformity and stability of segmented PEM fuel cells, J. Power Sources 181 (2008) 251. 
[52] I.A. Schneider, S.A. Freunberger, D. Kramer, A. Wokaun, G.G. Scherer, Oscillations in gas channels. Part I. The forgotten player in impedance spectroscopy in PEFCs, J. Electrochem. Soc. 154 (2007) B383.

[53] I.A. Schneider, D. Kramer, A. Wokaun, G.G. Scherer, Oscillations in gas channels. Part II. Unraveling the characteristics of the low frequency loop in air-fed PEFC impedance spectra, J. Electrochem. Soc. 154 (2007) B770.

[54] D.G. Sanchez, P.L. Garcia-Ybarra, PEMFC operation failure under severe dehydration, Int. J. Hydrogen Energy 37 (2012) 7279.

[55] M. Schulze, E. Gülzow, St. Schönbauer, T. Knori, R. Reissner, Segmented cell as toll for development of fuel cells and error prevention/prediagnostic in fuel cell stack, J. Power Sources 173 (2007) 19.

[56] D. Spernjak, J. Fairweather. R. Mukundan, T. Rockward, R.L. Borup, Influence of the microporous layer on carbon corrosion in the catalyst layer of a polymer electrolyte membrane fuel cell, J. Power Sources 214 (2012) 386.

[57] T.V. Reshetenko, G. Bender, K. Bethune, R. Rocheleau, Systematic study of back pressure and anode stoichiometry effects on spatial PEMFC performance distribution, Electrochim. Acta 56 (2011) 8700 .

[58] T.V. Reshetenko, G. Bender, K. Bethune, R. Rocheleau, Systematic studies of the gas humidification effects on spatial PEMFC performance distributions, Electrochim. Acta 69 (2012) 220 .

[59] R. Lin, E. Gülzow, M. Schulze, K.A. Friedrich, Investigation of membrane pinhole effects in polymer electrolyte fuel cells by locally resolved current density, J. Electrochem. Soc. 158 (2011) B11. 
[60] T.V. Reshetenko, G. Bender, K. Bethune, R. Rocheleau, Application of a segmented cell setup to detect pinhole and catalyst loading defects in proton exchange membrane fuel cells, Electrochim. Acta 76 (2012) 16.

[61] T.V. Reshetenko, G. Bender, K. Bethune, R. Rocheleau, Effects of local variations of the gas diffusion layer properties on PEMFC performance using a segmented cell system, Electrochim. Acta 80 (2012) 368.

[62] T.V. Reshetenko, J. St-Pierre, R. Rocheleau, Effects of local gas diffusion layer gas permeability variations on spatial proton exchange membrane fuel cells performance, J. Power Sources $241(2013) 597$.

[63] R. Borup, R. Mukundan, J. Davey, J. Spendelow, P. Mukherjee, D. Wood, M. Nelson, F. Garzon, M. Arif, D. Jacobson, D. Hussey, In situ PEM fuel cell water managements, LRD42b3, 2009 Fuel Cell Seminar, November 16-19, 2009, Palm Springs, CA, USA.

[64] L.C. Pérez, J. Ihonen, J.M. Sousa, A. Mendes, Use of segmented cell operated in $\mathrm{H}_{2}$ recirculation mode to detect water accumulation in PEMFC, Fuel Cells 13 (2013) 203.

[65] A. Lamibrac, G. Maranzana, O. Lottin, J. Mainka, S. Didierjean, A. Thomas, C. Moyne, Experimental characterization of internal currents during the start-up of a PEMFC, J. Power Sources 196 (2011) 9451.

[66] D. Liang, Q. Shen, M. Hou, Z. Shao, B. Yi, Study of the cell reversal process of large area PEMFC under fuel starvation, J. Power Sources 194 (2009) 847.

[67] M. Dou, M. Hou, Q. Shen, H. Znahg, W. Lu, Z. Shao, B. Yi, Behaviors of PEMFC under oxidant starvation, J. Power Sources 196 (2011) 2759.

[68] Z. Liu, L. Yang, Z. Mao, W. Zhuge, Y. Zhang, L. Wang, Behavior of PEMFC in starvation, J. Power Sources 157 (2006) 166. 
[69] T. Murahashi, T. Mitsumoto, E. Nishiyama, Current distribution of a PEMFC under CO poisoning, ECS Trans. 25 (2009) 869.

[70] D.J.L. Brett, P. Aguiar, N.P. Brandon, A.R. Kucernak, Measurement and modeling of carbon monoxide poisoning distribution within a polymer electrolyte fuel cell, Int. J. Hydrogen Energy 32 (2007) 863.

[71] T. Tingelöf, L. Hedström, N. Holmström, P. Alvfors, G. Lindbergh, The influence of $\mathrm{CO}_{2}, \mathrm{CO}$ and air bleed on the current distribution of a polymer electrolyte fuel cell, Int. J. Hydrogen Energy 33 (2008) 2064.

[72] M. Boaventura, H. Sander, K.A. Friedrich, A. Mendes, The influence of CO on the current density distribution of high temperature polymer electrolyte membrane fuel cells, Electrochim. Acta 56 (2011) 9467.

[73] S. Kirsch, R. Hanke-Rauschenbach, B. Stein, R. Kraume, K. Sundmacher, The electrooxidation of $\mathrm{H}_{2}, \mathrm{CO}$ in a model PEN fuel cell: oscillations, chaos, pulses, J. Electrochem. Soc. 160 (2013) F436.

[74] T.V. Reshetenko, K. Bethune, R. Rocheleau, Spatial PEMFC performance under CO poisoning at a low conventration using a segmented cell system, J. Power Sources 218 (2012) 412.

[75] T.V. Reshetenko, K. Bethune, M.A. Rubio, R. Rocheleau, Study of low concentration CO poisoning of $\mathrm{Pt}$ anode in a proton exchange membrane fuel cell using spatial electrochemical impedance spectroscopy, J. Power Sources 269 (2014) 344.

[76] Ch. Wieser, A. Helmbold, E. Gülzow, A new technique for two-dimensional current distribution measurements in electrochemical cells, J. Appl. Electrochem. 30 (2000) 803. 
[77] G. Bender, M.S. Wilson, T.A. Zawodzinski, Further refinements in the segmented cell approach o diagnosing performance in polymer electrolyte fuel cells, J. Power Sources 123 (2003) 163.

[78] T.E. Springer, T.A. Zawodzinski, M.S. Wilson, S. Gottesfeld, Characterization of polymer electrolyte fuel cells using AC impedance spectroscopy, J. Electrochem. Soc. 143 (1996) 587.

[79] B. Müller, N. Wagner, W. Schnurnberger, Change of electrochemical impedance spectra with time during CO-poisoning of the Pt anode in a membrane fuel cell, in Proton conducting membrane fuel cell II ed. S. Gottesfeld, T.F. Fuller, Electrochem. Soc, Proc. 98027 (1999) 187199.

[80] M. Ciureanu, H. Wang, Electrochemical impedance study of electrode-membrane assemblies in PEM fuel cells. I. Electro-oxidation of $\mathrm{H}_{2}$ and $\mathrm{H}_{2} / \mathrm{CO}$ mixtures on Pt-based gas-diffusion electrodes, J. Electrochem. Soc. 146 (1999) 4031.

[81] C.A. Schiller, F. Richter, E. Güzlow, N. Wagner, Relaxation impedance as a model for the deactivation mechanism of fuel cells due to CO poisoning, Phys. Chem. Chem. Phys. 3 (2001) 2113.

[82] N. Wagner, M. Schulze, Change of EIS during CO poisoning of the Pt and PtRu anodes in a membrane fuel cell (PEFC), Electrochim. Acta 48 (2003) 3899.

[83] N. Wagner, E. Güzlow, Change of electrochemical impedance spectra (EIS) with time during CO-poisoning of Pt-anode in a membrane fuel cell, J. Power Sources 127 (2004) 341.

[84] M. Ciureanu, H. Wang, Z. Qi, Electrochemical impedance study of membrane electrode assemblies in PEM fuel cells. II. Electrooxidation of $\mathrm{H}_{2}$ and $\mathrm{H}_{2} / \mathrm{CO}$ mixtures on $\mathrm{Pt} / \mathrm{Ru}$ based gas diffusion electrodes, J. Phys. Chem. B 103 (1999) 9645. 
[85] M. Ciureanu, H. Wang, Electrochemical impedance study of anode CO-poisoning in PEM fuel cells, J. New Mat. Electrochem. Systems 3 (2000) 107.

[86] X. Wang, I.-M. Hsing, Y.-J. Leng, P.-L. Yue, Model interpretation of electrochemical impedance spectroscopy and polarization behavior of $\mathrm{H}_{2} / \mathrm{CO}$ mixture oxidation in polymer electrolyte fuel cells, Electrochim. Acta 46 (2001) 4397.

[87] J.-D. Kim, Y.-I. Park, K. Kobayashi, M. Nagai, Effect of CO gas and anode-metal loading on $\mathrm{H}_{2}$ oxidation in proton exchange membrane fuel cell, J. Power Sources 103 (2001) 127.

[88] Y.-J. Leng, X. Wang, I-M. Hsing, Assessment of CO-tolerance for different Pt-alloy anode catalysts in polymer electrolyte fuel cell using ac impedance spectroscopy, J. Electroanal. Chem. 528 (2002) 145.

[89] F. Hajbolouri, B. Andreaus, G.G. Scherer, A. Wokaun, CO tolerance of commercial Pt and PtRu gas diffusion electrodes in polymer electrolyte fuel cells, Fuel Cells 4 (2004) 160.

[90] M.-C. Yang, Ch.-H. Hsueh, Impedance analysis of working PEMFCs in the presence of carbon monoxide, J. Electrochem. Soc. 153 (2006) A1043.

[91] R.D. Harington, M. Henderson, Impedance plane display of a reaction with an adsorbed intermediate, J. Electroanal. Chem. 39 (1972) 81.

[92] D.A. Harrington, B.E. Conway, AC impedance of faradaic reactions involving electrosorbed intermediates - I. Kinetic theory, Electrochim. Acta 32 (1987) 1703.

[93] Chu-Nan Cao, On the impedance plane displays for irreversible electrode reactions based on the stability conditions of the steady-state. I. One state variable besides electrode potential, Electrochim. Acta 35 (1990) 831.

[94] J.-P. Diard, B. Le Gorrec, C. Montella, Calculation, simulation and interpretation of electrochemical impedances. Part 3. Conditions for observation of low frequency inductive 
diagrams for a two-step electron transfer reaction with an adsorbed intermediate species, J. Electroanal. Chem. 326 (1992) 13.

[95] P. Córdoba-Torres, M. Keddam, R.P. Nogueira, On the intrinsic electrochemical nature of the inductance in EIS. A Monte Carlo simulation of the two-consecutive-step mechanism: The flat surface 2 D case, Electrochim. Acta 54 (2008) 518.

[96] C.A. Schiller, F. Ritcher, E. Güzlow, N. Wagener, Validation and evaluation of electrochemical impedance spectra of system with states that change with time, Phys. Chem. Chem. Phys. 3 (2001) 374.

[97] D.J.L. Brett, S. Atkins, N.P. Brandon, V. Vesocovic, N. Vasileiadis, A. Kucernak, Localized impedance measurements along single channel of a solid polymer fuel cell, Electrochem. Solid-State Lett. 6 (2003) A63.

[98] M. Gattrell, B. MacDougall, Reaction mechanisms of $\mathrm{O}_{2}$ reduction/evolution reactions, in: W. Vielstich, H.A. Gasteiger, A. Lamm, (Eds.), Handbook of Fuel Cells - Fundamentals, Technology and Applications, vol. 2. Electrocatalysis, John Wiley \& Sons, 2003, p. 443 (Chapter 30).

[99] P.N. Ross, Oxygen reduction resaction on smooth single crystal electrodes, in: W. Vielstich, H.A. Gasteiger, A. Lamm, (Eds.), Handbook of Fuel Cells - Fundamentals, Technology and Applications, vol. 2. Electrocatalysis, John Wiley \& Sons, 2003, p. 465 (Chapter 31).

[100] A.W.E. Chan, R. Hoffmann, W. Ho, Theorwtical aspects of photoinitiated chemisorption, dissociation and desorption of $\mathrm{O}_{2}$ on $\mathrm{Pt}(111)$, Langmuir 8 (1992) 1111.

[101] L.L. Kesmodel, L.H. Dubois, G.A. Somorjai, LEED analysis of acetylene and ethylene chemisorption on the Pt (111) surface: Evidence for ethylidyne formation, J. Chem. Phys. 70 (1979) 2180. 
[102] J.E. Demuth, On the structure of chemisorbed acetylene and ethylene on $\mathrm{Ni}, \mathrm{Pd}$ and $\mathrm{Pt}$ surfaces, Surf. Sci. 84 (1979) 315.

[103] A.B. Anderson, A.T. Hubbard, Theoretical determination of the structure of acetylene on Pt (111), Surf. Sci. 99 (1980) 384.

[104] S.P. Mehandru, A.B. Anderson, Dependence of CC and CH bond activation on d-band position: Acetylene on Pt (111) and Fe (100). An electrochemical model, J. Am. Chem. Soc. 107 (1985) 844.

[105] E.L. Muetterties, M.-V. Tsai, S.R. Kelemen, Chemistry of acetylene on platinum (111) and (100), Proc. Natl. Acad. Sci. USA 78 (1981) 6571.

[106] S. Gilman, Studies of hydrogen surface processes by the multipulse potentiodynamic method. Part 3. Kinetics of adsorption of ethylene and acetylene on platinum and the structure of the adsorbed layer at low potentials, Trans. Faraday Soc.62 (1966) 466.

[107] A.B. Delgado, A.M. Castro Luna, W.E. Triaca, A.J. Arvia, The adsorption and the potentiodynamic electrooxidation of acetylene on platinized platinum, J. Electrochem. Soc. 129 (1982) 1493.

[108] J.E. Demuth, The reaction of ethylene and acetylene with Pt (111) at room temperature: The formation of vinyl-like species, Surf. Sci. 80 (1979) 367.

[109] P.S. Cremer, X. Su, Y.R. Shen, G.A. Somorjai, Temperature-dependent rearrangements and reactions ofacetylene adsorbed on $\mathrm{Pt}$ (111) monitored in the range $125-381 \mathrm{~K}$ by sum frequency generation, J. Phys. Chem. 101 (1997) 6474.

[110] D.J. Burnett, A.M. Gabelnick, D.A. Fischer, A.L. Marsh, J.L. Gland, Mechanism of acetylene oxidation on the Pt (111) surface using in situ fluorescence yield near-edge spectroscopy, J. Catal. 230 (2005) 282. 
[111] S. Gilman, Studies of hydrogen surface processes by the multipulse potentiodynamic method. Part 4. Effect of potential on ethylene and acetylene adsorption on platinum, Trans. Faraday Soc.62 (1966) 481.

[112] K.G. Bogoslovskii, L.A. Mirkind, Acetylene adsorption on smooth platinum in the region of high positive potentials, Soviet Electrochemistry 13 (1977) 396.

[113] M.R. Rahman, M.I. Awad, F. Kitamura, T. Okajima, T. Ohsaka, A comparative study of ORR at the Pt electrode in ammonium ion-contaminated $\mathrm{H}_{2} \mathrm{SO}_{4}$ and $\mathrm{HClO}_{4}$ solutions, J. Power Sources 220 (2012) 65.

[114] H.J. Davitt, L.F. Albright, Electrochemical hydrogenation of ethylene, acetylene and ethylene-acetylene mixtures, J. Electrochem. Soc. 118 (1971) 236.

[115] B.J, Piersma, E. Gileadi, The mechanism of electrochemical oxidation of organic fuels, in: J.O’M. Bockris (Ed.) Modern aspects of electrochemistry, Olenum Press, New York, vol. 4, 1966, p. 47.

[116] R.L. Palmer, Molecular beam study of oxygen and $C_{2}$ hydrocarbon chemisorption and reactions on Pt (111), J. Vac. Sci. Technol. 12 (1975) 1403.

[117] C.E. Megiris, P. Berlowitz, J.B. Butt, H.H. Kung, Temperature programmed study of acetylene on a clean H-covered and O-covered Pt (111) surface, Surf. Sci. 159 (1985) 184.

[118] T.M. Beloslyudova, D.V. Sokol'skii, The behavior of ethylene and acetylene on a platinum catalyst in aqueous solution, Soviet Electrochemistry 1 (1965) 1056.

[119] X. Lu, 1. Liu, W.Guo, L. Zhao, H. Shan, Theoretical analysis of the conversion mechanism of acetylene to ethylidyne on Pt (111), Phys. Chem. Chem. Phys. 14 (2012) 5642. 
[120] A. Ohma, T. Ichiya, K. Fushinobu, K. Okazaki, Theoretical analysis of oxygen reduction reaction and $\mathrm{H}_{2} \mathrm{O}_{2}$ formation and the impact of $\mathrm{CF}_{3} \mathrm{SO}_{3} \mathrm{H}$ coverage on $\mathrm{Pt}$ (111), Surf. Sci. 604 (2010) 965 .

[121] L.D. Burke, F.A. Lewis, C. Kemball, Hydrogenation of acetylene at palladized palladium and platinized platinum electrodes, Trans. Faraday Soc. 60 (1965) 919.

[122] J.T. Müller, P.M. Urban, W.F. Hölderich, Impedance studies on direct methanol fuel cell anodes, J. Power Sources 84 (1999) 157.

[123] Z. Duan, G. Wang, Comparison of reaction energetics for oxygen reduction reactions on Pt (100), Pt (111), Pt/Ni (100) and Pt/Ni (111) surfaces: a first principles study, J. Phys. Chem. $117(2013) 6284$.

[124] A. Parthasarathy, S. Srinivasan, A.J. Appleby, C.R. Martin, Temperature dependence of electrode kinetics of oxygen reduction at the platinum/nafion interface. A microelectrode investigation, J. Electrochem. Soc. 139 (1992) 2530.

[125] S. Mukerjee, S. Srinivasan, M.P. Soriaga, J. McBreen, Effect of preparation conditions of Pt alloys on their electronic, structural and electrocatalytic activities for oxygen reduction XRD, XAS, and electrochemical studies, J. Phys. Chem. 99 (1995) 4577.

[126] R. Borup, J. Meyers, B. Pivovar, Y.S. Kim, R. Mukundan, N. Garland, D. Myers, M. Wilson, F. Garzon, D. Wood, P. Zelenay, K. More, K. Stroh, T. Zawodzinski, J. Boncella, J.E. McGrath, M. Inaba, K. Miyatake, M. Hori, K. Ota, Z. Ogumi, S. Miyata, A. Nishikata, Z. Siroma, Y. Uchimoto, K. Yasuda, K. Kimijima, N. Iwashita, Scientific aspects of polymer electrolyte fuel cell durability and degradation, Chem. Rev. 107 (2007) 3904.

[127] A.Z. Weber, A. Kusoglu, Unexplained transport resistances for low-loaded fuel-cell catalyst layers, J. Mater. Chem. A 2 (2014) 17207 
Table 1. Summary of performance details under $\mathrm{C}_{2} \mathrm{H}_{2}$ exposure and operation at different current densities. Localized current density under $\mathrm{C}_{2} \mathrm{H}_{2}$ exposure refers to steady state operation.

\begin{tabular}{|c|c|c|c|c|c|c|}
\hline \multirow[t]{2}{*}{$\begin{array}{l}\text { Current density } \\
{\left[\mathrm{A} \mathrm{cm}^{-2}\right]}\end{array}$} & \multirow[t]{2}{*}{$\begin{array}{c}\text { Initial cell } \\
\text { voltage }[\mathrm{V}]\end{array}$} & \multirow[t]{2}{*}{$\begin{array}{c}\text { Transition } \\
\text { period }\end{array}$} & \multirow[t]{2}{*}{$\begin{array}{c}\text { Voltage during } \mathrm{C}_{2} \mathrm{H}_{2} \\
\text { exposure [V] }\end{array}$} & \multicolumn{2}{|c|}{$\begin{array}{l}\text { Changes in localized current density } \\
\text { under } \mathrm{C}_{2} \mathrm{H}_{2} \text { exposure [\%] }\end{array}$} & \multirow[t]{2}{*}{$\begin{array}{c}\text { Voltage loss after } \\
\text { recovery }[\mathrm{V}]\end{array}$} \\
\hline & & & & Segment 1 & Segment 10 & \\
\hline 0.1 & 0.817 & no & 0.785 & -61 & +41 & 0.027 \\
\hline 0.2 & 0.770 & no & 0.720 & -95 & +59 & 0.023 \\
\hline 0.4 & 0.750 & $8 \mathrm{~h}$ & 0.130 & -52 & +93 & 0.065 \\
\hline 0.6 & 0.705 & $60 \mathrm{~min}$ & 0.105 & -27 & +32 & 0.058 \\
\hline 1.0 & 0.662 & $40 \mathrm{~min}$ & 0.074 & -19 & +20 & 0.015 \\
\hline
\end{tabular}


Table 2. ECA and performance changes after $\mathrm{C}_{2} \mathrm{H}_{2}$ exposure at different current densities.

\begin{tabular}{|c|c|c|c|c|}
\hline \multirow{2}{*}{$\begin{array}{c}\text { i of } \mathrm{C}_{2} \mathrm{H}_{2} \text { exposure } \\
{\left[\mathrm{A} \mathrm{cm}^{-2}\right]}\end{array}$} & \multicolumn{2}{|c|}{$\Delta \mathrm{ECA}[\%]$} & \multirow{2}{*}{$\begin{array}{c}\Delta \text { Voltage } \\
{[\mathrm{mV}]}\end{array}$} & \multirow[t]{2}{*}{ Analysis of voltage overpotentials } \\
\hline & Anode & Cathode & & \\
\hline 0.1 & -12.2 & -21.6 & -30 to 0 & Increase in activation losses $(5-30 \mathrm{mV})$ \\
\hline 0.2 & -4.9 & -1.0 & +30 & Decrease in mass transfer losses $(\sim 30 \mathrm{mV})$ \\
\hline 0.4 & -3.4 & -21.5 & -50 to -10 & Increase in activation $(10-25 \mathrm{mV})$ and mass transfer losses $(5-30 \mathrm{mV})$ \\
\hline 0.6 & +0.1 & -9.5 & -50 to 20 & Increase in activation $(0-15 \mathrm{mV})$ and variation in mass transfer losses $(-10$ to $20 \mathrm{mV})$ \\
\hline 1.0 & -7.9 & -14.4 & -5 to 5 & No significant impact of any overpotential \\
\hline
\end{tabular}




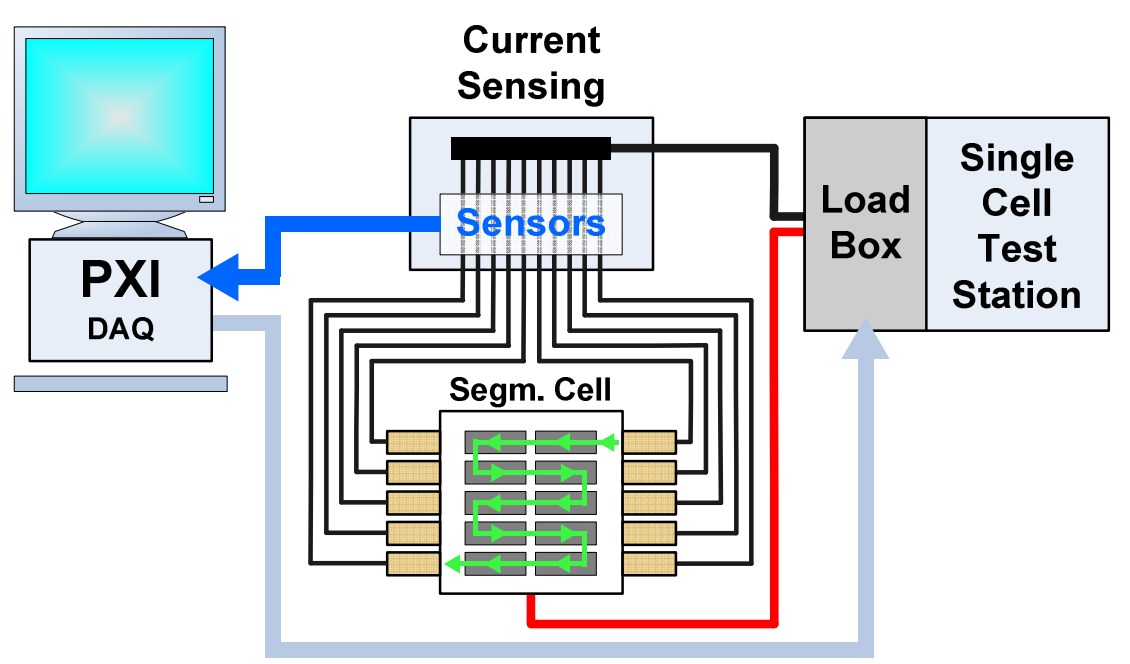




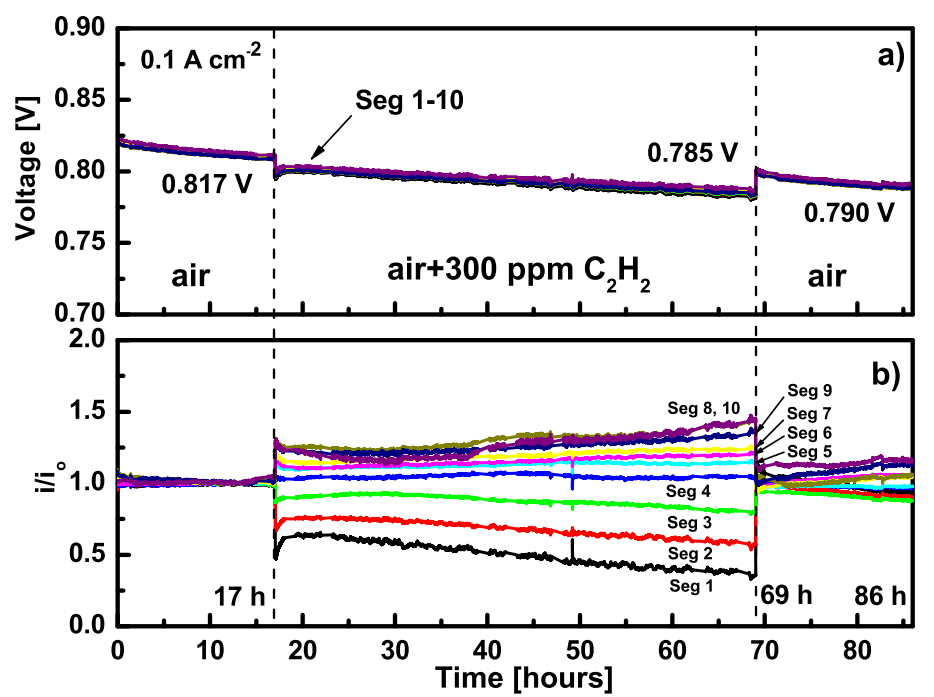

$\operatorname{Seg} 1,-\operatorname{Seg} 2,-\operatorname{Seg} 3,-\operatorname{Seg} 4,-\operatorname{Seg} 5$

$\operatorname{Seg} 6,-\operatorname{Seg} 7,-\operatorname{Seg} 8,-\operatorname{Seg} 9,-\operatorname{Seg} 10$ 


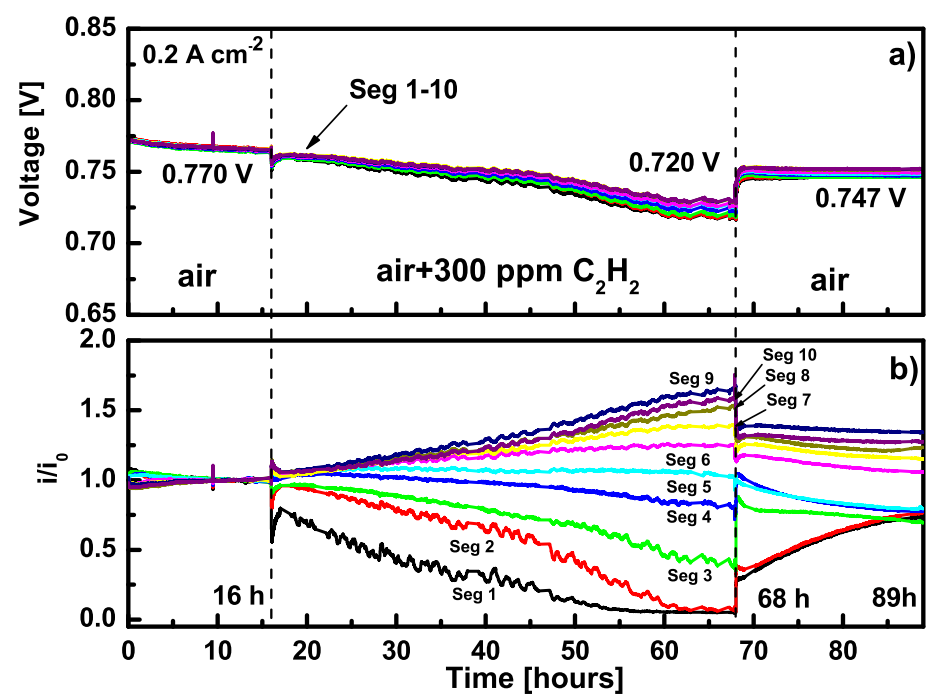

$\operatorname{Seg} 1,-\operatorname{Seg} 2,-\operatorname{Seg} 3,-\operatorname{Seg} 4,-\operatorname{Seg} 5$

$\operatorname{Seg} 6,-\operatorname{Seg} 7,-\operatorname{Seg} 8,-\operatorname{Seg} 9,-\operatorname{Seg} 10$ 


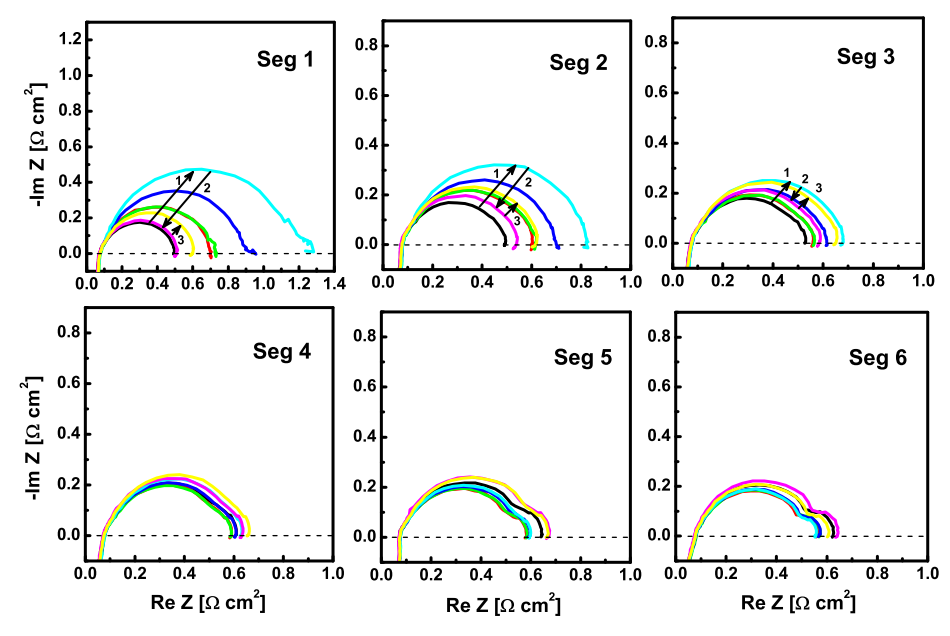




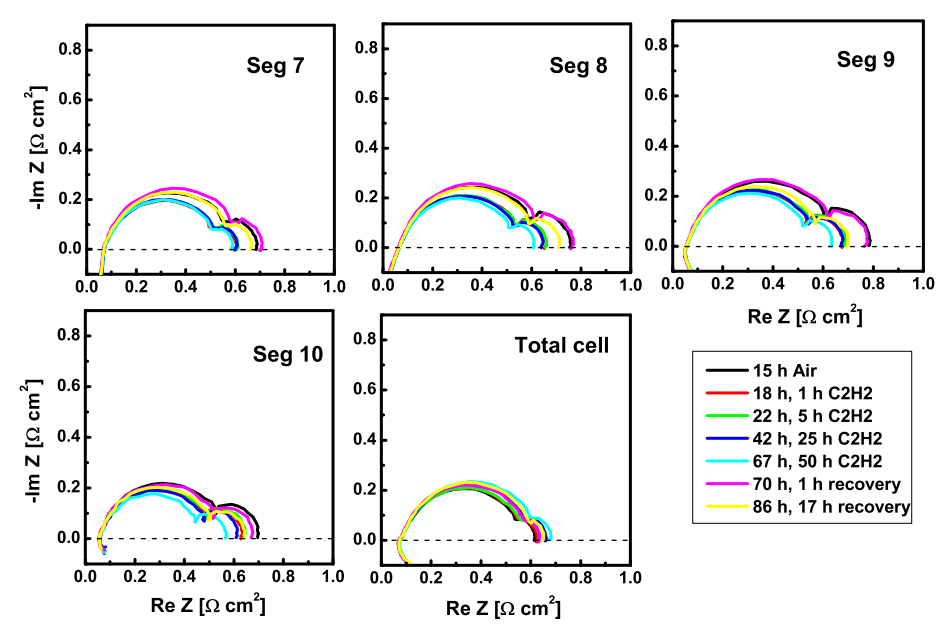




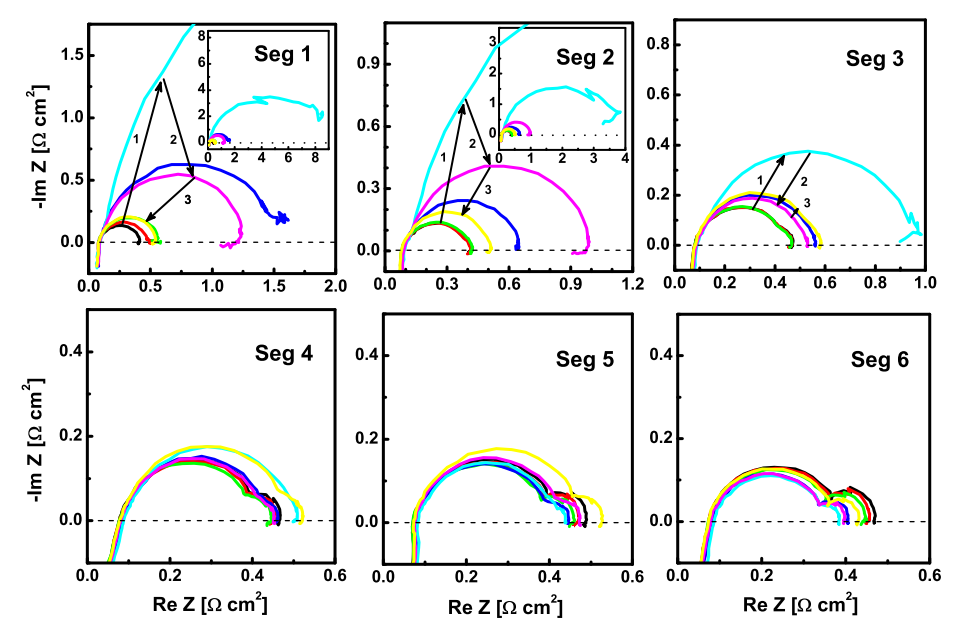




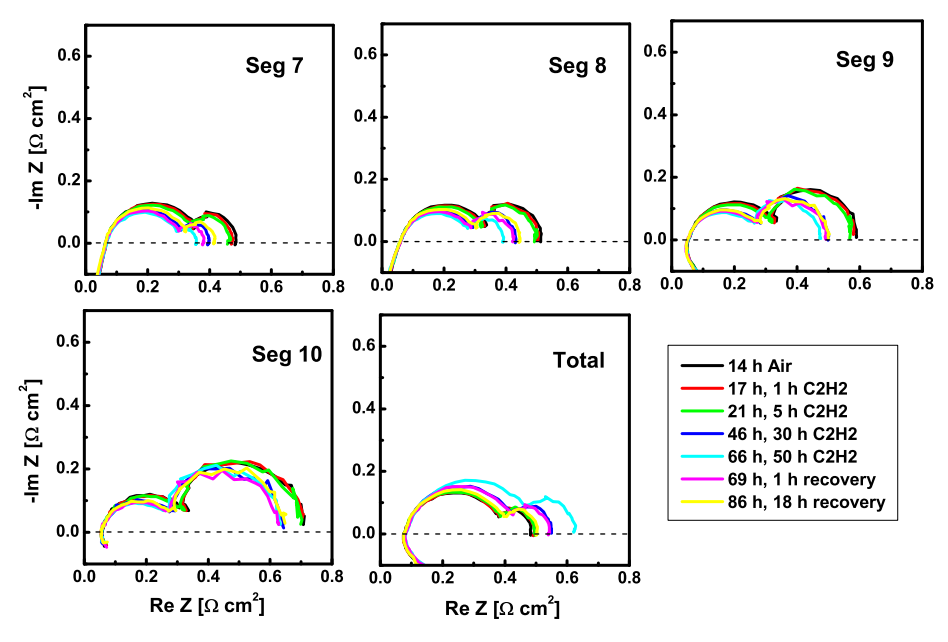




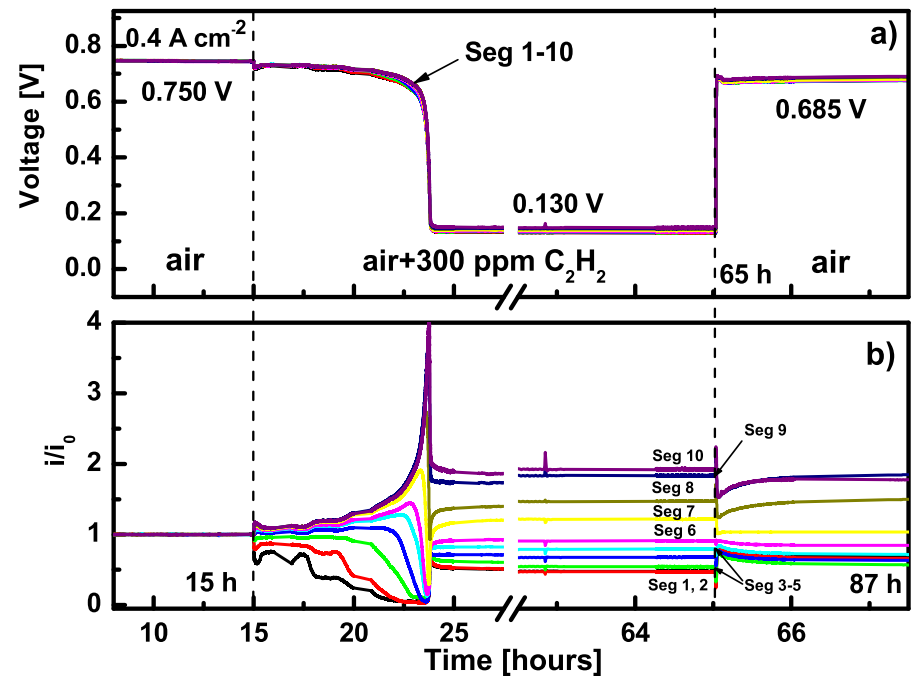




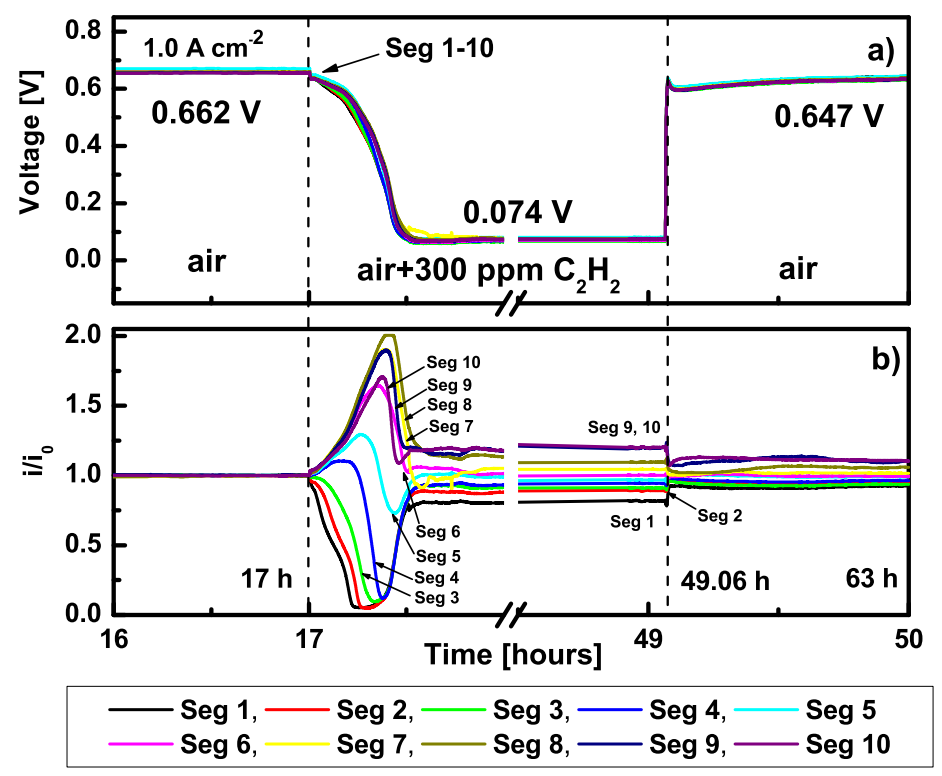




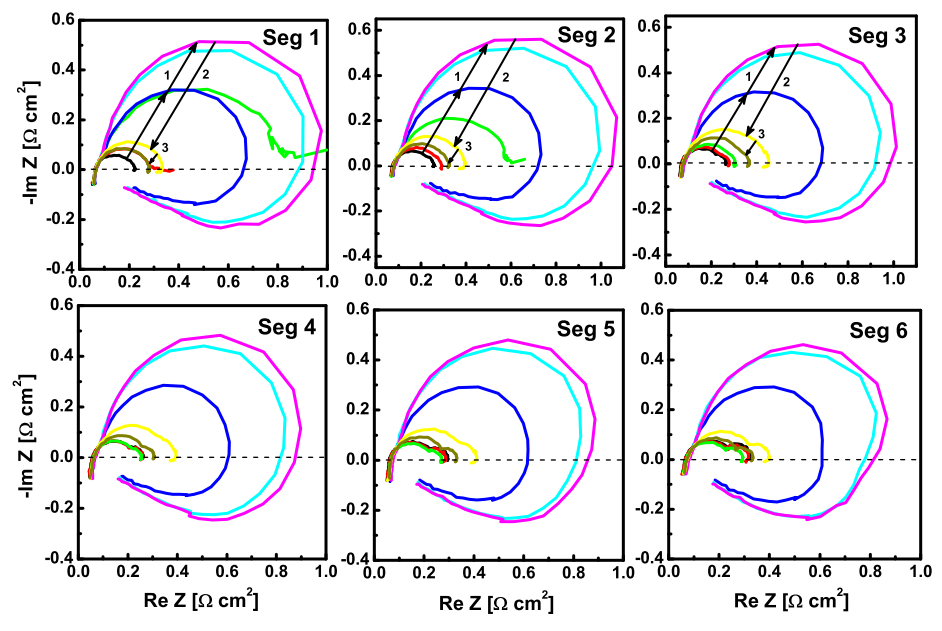




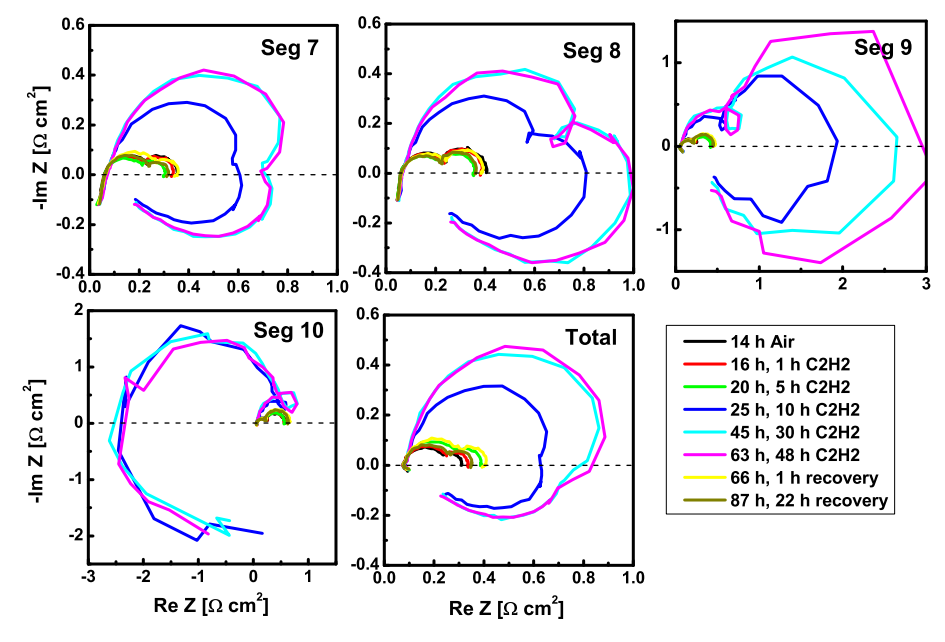




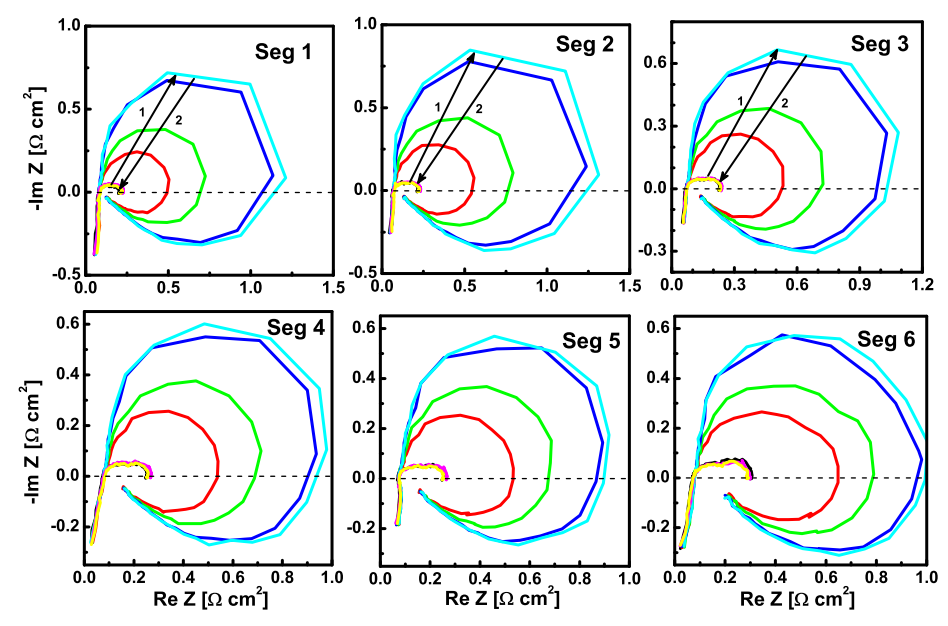



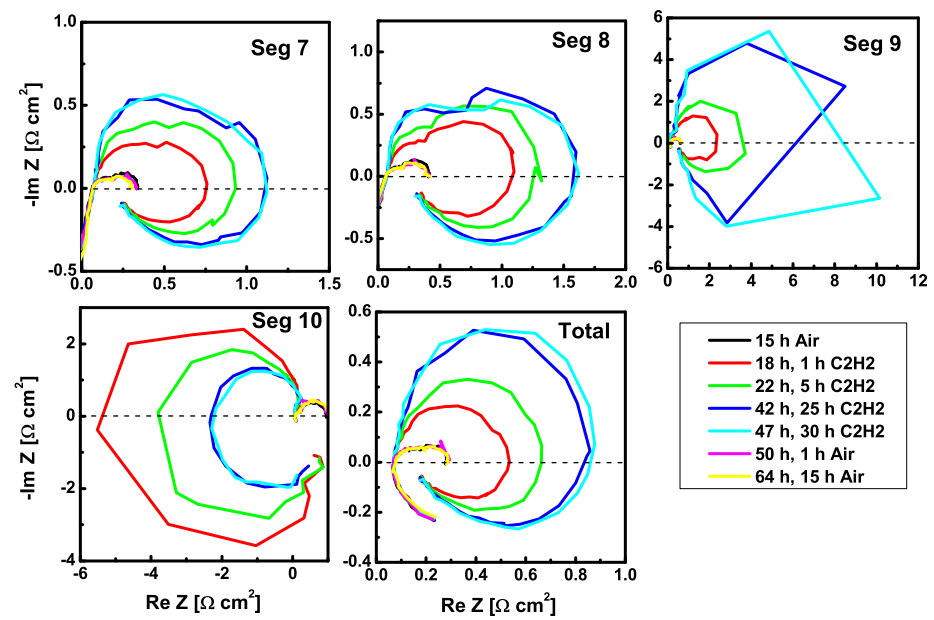

$18 \mathrm{~h}, 1 \mathrm{~h} \mathrm{C2H} 2$ $22 \mathrm{~h}, 5 \mathrm{~h} \mathrm{C2H} 2$ $-42 \mathrm{~h}, 25 \mathrm{~h} \mathrm{C} 2 \mathrm{H} 2$ $-47 \mathrm{~h}, 30 \mathrm{~h}$ C2H2 $50 \mathrm{~h}, 1 \mathrm{~h}$ Air

$64 \mathrm{~h}, 15 \mathrm{~h}$ Air 


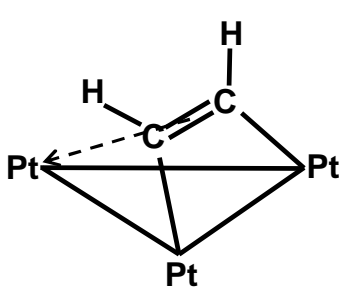

a)

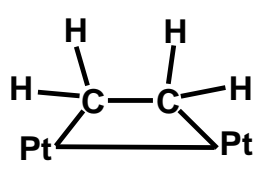

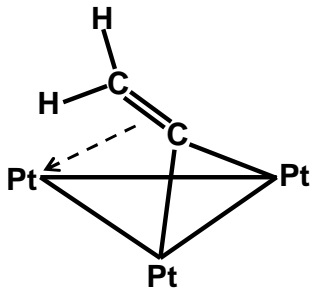

b)

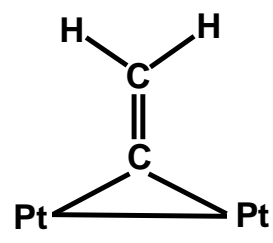

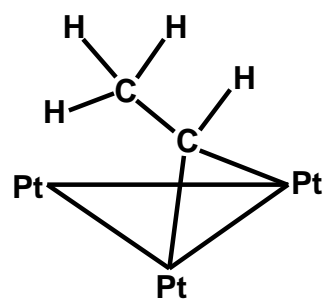

c)

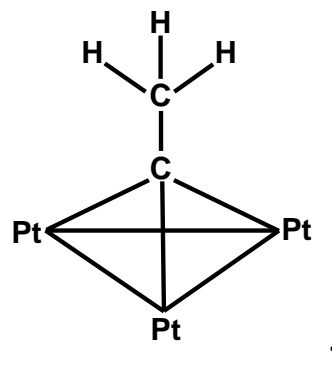

f)

e) 


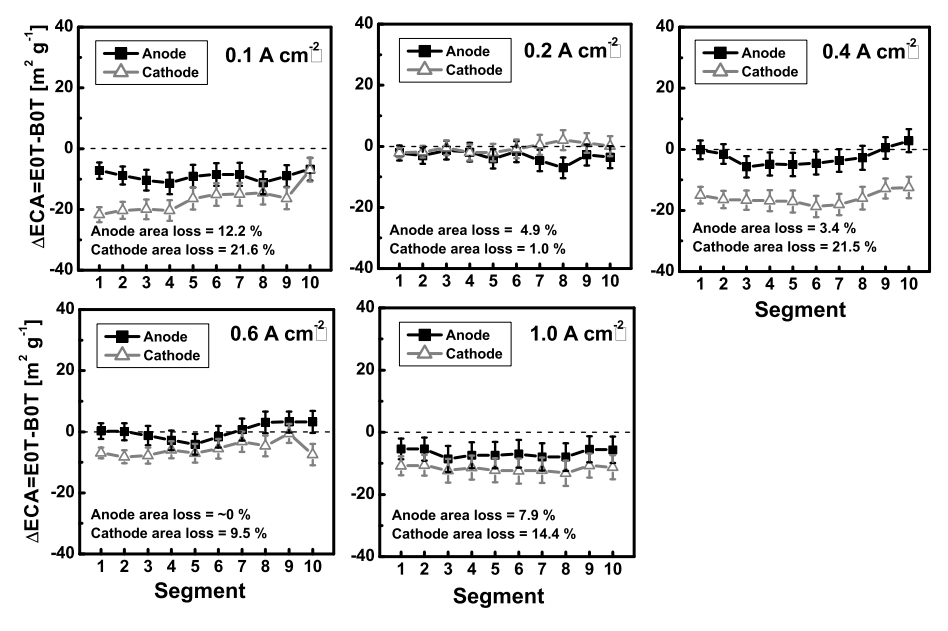




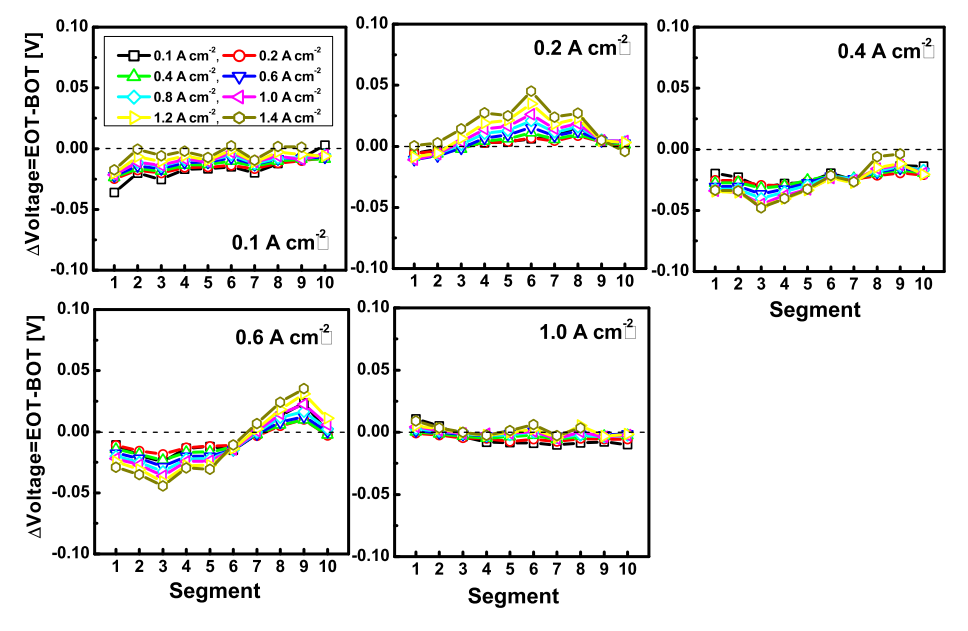


Effects of $\mathrm{C}_{2} \mathrm{H}_{2}$ on spatial PEMFC performance and EIS were studied with a segmented cell. The experiments were done under galvanostatic control of overall cell current $\left(0.1-1.0 \mathrm{~A} \mathrm{~cm}^{-2}\right)$. Injection of $\mathrm{C}_{2} \mathrm{H}_{2}$ resulted in a voltage decrease and redistribution of segments' currents.

Localized currents redistribution under $\mathrm{C}_{2} \mathrm{H}_{2}$ exposure depends on operating current/voltage. Oxidation/reduction of $\mathrm{C}_{2} \mathrm{H}_{2}$ on $\mathrm{Pt}$ occurs at high/low cell potential, respectively. 